\title{
Synopsis of the plants known as medicinal and poisonous in Northeast of Brazil
}

\author{
Maria de Fátima Agra*, Patrícia França de Freitas, José Maria Barbosa-Filho \\ Universidade Federal da Paraíba, Laboratório de Tecnologia Farmacêutica, Caixa Postal 5009, \\ 58051-970, João Pessoa, PB, Brazil
}

\begin{abstract}
RESUMO: "Sinopse das plantas conhecidas como medicinais e venenosas no Nordeste do Brasil". Este trabalho teve como objetivo um levantamento das plantas e dos seus usos como medicinais, às quais são utilizadas com fins terapêuticos na região nordeste do Brazil. A área de estudo é reconhecida por uma rica biodiversidade, principalmente de plantas e de habitates, abrangendo desde a Floresta Amazônica, Floresta Atlântica, sistemas de mangues e dunas costeiras, até florestas secas e savanas. Como resultados, foram registrados um total de 483 espécies pertencentes a 79 familias e suas informações etnomedicinais. Este estudo sugere para a grande importância para a investigação das espécies farmacologicamente ainda não estudadas, uma vez que seus usos populares estão registrados.
\end{abstract}

Unitermos: Plantas medicinais, plantas tóxicas, Nordeste do Brasil, ethnomedicina, etnobotânica.

\begin{abstract}
The objective of this work is a survey of the species of plants and their alleged therapeutic uses which are utilized in Northeast region of Brazil. The area of this study is well known for its rich diversity of species of plants and habitats, which range from rainforest, atlantic forest, coastal dunes systems and mangroves, to dry forests and savannas. A total of 483 species belonging to 79 families along with their ethnomedicinal information have been recorded. This study aims at emphasizing the greatest importance of investigating those species of plants which have not been the subject of any pharmacological study, although their popular uses have been reported.
\end{abstract}

Keywords: Medicinal plants, toxic plants, Northeast of Brazil, ethnomedicine, etnobotany.

\section{INTRODUCTION}

Folk medicines, mainly based on plants, enjoy a respectable position today, especially in the developing countries, where the availability of modern health services is limited. Safe, effective and inexpensive indigenous remedies are gaining popularity among the people of both urban and rural areas. Information from ethnic groups on indigenous traditional medicine has played a vital role in the discovery of novel products from plants as chemotherapeutic agents.

According to the current estimate by World Health Organization (WHO, 1999), even in many developed countries a great portion of the population makes use of traditional health remedies, especially the medicinal plants. Although a easy access to the modern medicine is available in these countries, the use of medicinal herbs has kept its popularity for historical and cultural reasons. On the other hand, in the developing countries $65-80 \%$ of the population depends exclusively on the medicinal plants for the basic healthcare.

The study of traditional uses of plants and their products in the Northeast region of Brazil has been gradually increasing during the last few years which resulted in a significant body of publications in this area (Braga, 1960; Agra, 1982, 1996; Matos, 1989, 2000; Moura; Agra, 1989; Agra; Silva, 1993; Baracho; Agra, 1995; Rego, 1995; Agra; Bhattacharyya, 1999; Agra et al., 1996, 2005, 2007; Torres et al., 2005; Morais et al., 2005; Albuquerque et al., 2006; and references therein).

The principal ecosystem of the Northeast of Brazil is the biome "caatinga", an Indian word, meaning "open forest", so named because of its appearance during the dry season (Ab'Saber, 1980; Lleras, 1997). It consists of extensive semi-arid plains found mainly in Northeast region, from Piauí to North of Minas Gerais, with the exception of the State of Maranhão which has no "caatinga". The plants in the surrounding area form an integral part of culture of these people and the information about plants is passed on from generation to generation.

The traditional healers who use medicinal plants are known as "raizeiros" to the people of the Northeast region of Brazil. The "raizeiros" have a commendable knowledge of the medicinal plants that grow in and around their area (Agra et al., 2005, 2007). This knowledge of traditional healing, mainly with the use of wild plants is now fast disappearing due to modernization and to change their traditional lifestyle for more contemporary 
one. That is why, there is an urgent need for studying and recording this precious knowledge of the traditional uses of plants as herbal remedies which have actually declined due to scarcity of species caused mainly by the human activity coupled with long periods of the dry season. In this context the conservation and scientific verification of rare and lesser known medicinal plants assume greater significance.

The present study is focused on a survey of literature of the medicinal uses of native, naturalized and cultivated plant species, which are utilized for therapeutic purposes in all States of Northeast of Brazil extending from Maranhão to Bahia.

Ethnomedicinal information of plants used in the popular medicine in Northeast of Brazil has also been carried out in recent pharmacobotanical studies (Silva et al. (2002), Leal and Agra (2004), Basílio et al. (2005), Silva and Agra (2005), inter alia. Although, there are still many gaps in our knowledge of the uses of the plants of this region in ethnomedicine, some of the main traits are presented here.

\section{MATERIAL AND METHODS}

\section{Study area}

The general area of the Brazilian Northeast is $1,561,177.8 \mathrm{~km}^{2}$ which extends from about $02^{\circ} 54^{\prime}$ to $17^{\circ} 21^{\prime} \mathrm{S}$ and from $35^{\circ}$ to $46^{\circ} 30^{\prime} \mathrm{W}$ that includes nine States: Maranhão, Piauí, Ceará, Rio Grande do Norte, Paraíba, Pernambuco, Alagoas, Sergipe and Bahia. It is a region rich in plant diversity and habitats ranging from the rainforest of North of Maranhão, to atlantic forest, coastal dunes systems, mangroves, dry forests and savannas.

\section{Format}

The information of the plants and their ethnomedicinal uses are compiled in Table 1, which provides the botanical family and scientific names of species (the specific binomial). The vernacular names, parts used, popular indication and uses are also presented. The abbreviations of the authors follow Brummitt and Powel (1992). The cultivated species in Northeast of Brazil are indicated by only one asterisk, and the species that are imported from outside of Brazil have two asterisks.

\section{RESULTS AND DISCUSSION}

The ethnomedicinal investigation of the plants known as medicinal and/or poisonous in Northeast of Brazil was done on a total of 483 species belonging to about 79 families. Of these, 466 species corresponding to about $96.5 \%$ are recorded by their medicinal use, eight as both medicinal and poisonous and 27 as only poisonous.
The floristic diversity observed is dominated by higher plants with only one species, Selaginella convoluta Spreng, belonging to the Ferns was reported.

The predominance of higher plants used for medicinal purposes in Northeast of Brazil strengthens our results from previous studies by us (Agra, 1982, 1996; Agra; Silva, 1993; Baracho; Agra, 1995; Agra; Bhattacharyya, 1999; Agra et al., 1996, 2005, 2007) as well as by other authors in different areas of Brazil (Souza et al., 2004; Luna et al., 2005; Vendruscocolo et al., 2005; Albuquerque et al., 2006; Mendes; Carlini, 2006) and other countries around the world such as Saudi Arabia (Rahman et al., 2004), Bolivia (Macía et al., 2005), Italy (Scherrer et al., 2005), Morocco (Tahraoui et al., 2007), inter alia.

Most species have several medicinal uses, various parts used and have different modes of preparation. Sixteen species were referred to having only one medicinal indication (Table 1). The medicinal activity of the highest number of species was reported for the treatment of respiratory system. This was followed by gatrointestinal disorders against parasites (15), stomach aches (24) and liver diseases. Most plants are used internally, and are prepared in form of decoction, infusion, maceration and as juice. According to Agra et al. (2007), some preparations are called as garrafada (bottled), and constitute a mixture of different plants, mainly roots and stem-barks, which are macerated for a few days to a week in a local alcoholic drink called cachaça. Other recipes are prepared as syrups with sugar or honey that are known in the folklore as "lambedor" that are used mainly for illness of children and in respiratory diseases as expectorant.

\section{CONCLUSION}

This study records the use of 483 plants with potential bioactive properties. Many of the reported species have not been studied for their chemical constituents and/ or biological activities. The study aims at emphasizing the greatest importance of investigation of those species that have not been the subject of pharmacological study, although their popular uses have been reported.

\section{ACKNOWLEDGEMENTS}

This work was supported by grants from the Conselho Nacional de Pesquisa e Desenvolvimento (CNPq). Thanks to Dr. J. Bhattacharyya for revision of the English and Dulce Gonçalves for her technical support.

\section{REFERENCES}

Ab'Saber AN 1980. O Domínio morfoclimático semi-árido das caatingas brasileiras. Craton Intracraton Escr Doc. 6: 35.

Agra MF 1982. Contribuição ao estudo das plantas medicinais na Paraíba. Cienc Cult 33: 64-66. 
Agra MF, Silva MG 1993. Plantas medicinais usadas como cosméticos na Paraíba (Brasil) e na literatura. Rev Bras Farm 74: 42-44.

Agra MF, Rocha EA, Formiga SC, Locatelli E 1994. Plantas medicinais dos Cariris Velhos, Paraíba. Parte I: subclasse Asteridae. Rev Bras Farm 75: 61-64.

Agra MF 1996. Plantas da medicina popular dos Cariris Velhos, Paraíba, Brasil: espécies mais comuns. João Pessoa: Editora União.

Agra MF, Locatelli E, Rocha EA, Baracho GS, Formiga SC 1996. Plantas medicinais dos Cariris Velhos, Paraíba. Parte II: subclasses Magnoliidae, Caryophyllidae, Dilleniidae e Rosidae. Rev Bras Farm 77: 97-102.

Agra MF, Bhattacharyya J 1999. Ethnomedicinal and phytochemical investigation of the Solanum species in the Northeast of Brazil. In: M. Nee, D.E. Symon, R.N.; Lester \& J. P. Jessop (editors) Solanaceae IV. Kew: Royal Botanic Gardens, p.341-343.

Agra MF, Freitas PF, Câmara CA, Silva TMS, Almeida RN, Amaral FMM, Almeida MZ, Medeiros IA, Moraes MO, Barbosa-Filho JM, Nurit K, Oliveira FS, Freire KRL, Morais LCSL, Rêgo TJAS, Barros RFM 2005. Medicinais e produtoras de princípios ativos. In: Sampaio EVSB, Pareyn FGC, Figueirôa JM, SantosJr AG (editores) Espécies da Flora Nordestina de Importância Econômica Potencial. Recife: Associação Plantas do Nordeste, p.135-198.

Agra MF, Baracho GS, Nurit K, Basílio IJLD, Coelho VPM, 2007. Medicinal and poisonous diversity of the flora of "Cariri Paraibano", Brazil. J Ethnopharmacol doi:10.1016/j.jep.2006.12.007.

Albuquerque AP, Monteiro JM, Ramos MA., Amorim ELC 2006. Medicinal and magic plants from a public market in Northeastern Brazil. J Ethnopharmacol doi: 10.1016/j.jep.2006.09.010.

Baracho GS, Agra MF 1995. Etnomedicina da Família Malvaceae nos Cariris Velhos, Paraíba, Brasil. Rev Bras Farm 76: 48-52.

Basílio IJLD, Nurit K, Agra MF 2005. Estudo farmacobotânico das folhas de três espécies do gênero Strychnos L. (Loganiaceae) do Nordeste do Brasil. Acta Farm Bonaerense 24: 356-365.

Braga R 1960. Plantas do Nordeste, especialmente do Ceará. $2^{\text {a }}$ Ed. Fortaleza: Imprensa Oficial.

Brummitt RK, Powel CE, 1992. Authors of Plant Names. Royal Botanic Gardens, Kew, Great Britain. 732 p.

Leal CKA, Agra MF 2005. Estudo farmacobotânico comparativo das folhas de Jatropha molissima (Pohl) Baill. e Jatropha ribifolia (Pohl) Baill. (Euphorbiaceae). Acta Farm Bonaerense 24: 5-13.

Lleras E, 1997. Caatinga of North-Eastern Brazil. In. S.D. Davis, V.H.Heywood, O. Herrera-MacBryde, J. Villa-Lobos and A.C. Hamilton (Eds.), Centres of Plant Diversity. A Guide and Strategy for their Conservation, vol. 3, IUCN Publications Unit, Cambridge, U.K., pp. 393396.

Luna JS, Santos AF, Lima MRF, Omena MC, Mendonça FAC, Bieber LW, Sant'Ana AEG 2005. A study of the larvicidal and molluscicidal activities of some medicinal plants from northeast Brazil. $J$ Ethnopharmacol 97:199-206.

Macía MJ, García E, Vidaurre PJ 2005. An ethnobotanical survey of medicinal plants commercialized in the markets of
La Paz and El Alto, Bolivia. J Ethnopharmacol 97: 337-350.

Matos FJA 1989. Plantas Medicinais: Guia de seleção e emprego de plantas usadas em fitoterapia no Nordeste do Brasil. Vol. II. Fortaleza: IOCE.

Matos FJA 2000. Plantas Medicinais: Guia de seleção e emprego de plantas usadas em fitoterapia no Nordeste do Brasil. $2^{\mathrm{a}}$ ed. Fortaleza: Imprensa Universitária, UFC.

Mendes FR, Carlini EA 2006. Brazilian plants as possible adaptogens: an ethnopharmacological surveys of books edited in Brazil. JEthnopharmacol doi:10.1016/ j.jep.2006.08.024.

Morais SM, Dantas JDP, Silva ARA, Magalhães EF 2005. Plantas medicinais usadas pelos índios Tapebas do Ceará. Rev Bras Farmacogn 15: 169-177.

Moura MDB, Agra MF 1989. Apocynaceae tóxicas e medicinais ocorrentes nos Estados de Pernambuco e Paraíba, Brasil. Acta Bot Bras 3: 273-279.

Rahman MA, Mossa JS, Al-Said MS, Al-Yahya MA, 2004. Medicinal plant diversity in the flora of Saudi Arabia 1: a report on seven plant families. Fitoterapia 75 : 149-161.

Rêgo TJAS, 1995. Fitogeografia das plantas medicinais do Maranhão, 2a ed. EDUFMA, São Luis, 133 p.

Scherrer AM, Motti R, Weckerle CS 2005. Traditional plant use in the areas of Monte Vesole and Ascea, Cilento National Park (Campania, Southern Italy). J Ethnopharmacol 97: 129-143.

Silva KN, Agra MF, Baracho GS 2002. Estudo etnomedicinal e farmacobotânico comparativo entre Passiflora foetida L. e Passiflora cincinnata Mast. (Passifloraceae). Rev Bras Farm 83: 51-55.

Souza GC, Haas APS, von Poser GL, Schapoval EES, Elisabetsky E 2004. Ethnopharmacological studies of antimicrobial remedies in the south of Brazil. $J$ Ethnopharmacol 90: 135-143.

Tahraoui A, El-Hilaly J, Israili ZH, Lyoussi B 2007. Ethnopharmacological survey of plants used in the traditional treatment of hypertension and diabetes in south-eastern Morocco (Errachidia province). $J$ Ethnopharmacol 110: 105-117.

Tôrres AR, Oliveira RAG, Diniz MFFM, Araújo EC 2005. Estudo sobre o uso de plantas medicinais em crianças hospitalizadas da cidade de João Pessoa: riscos e benefícios. Rev Bras Farmacogn 15: 373-380.

Vendruscolo GS, Rates SMK, Mentz LA 2005. Dados químicos e farmacológicos sobre as plantas utilizadas como medicinais pela comunidade do bairro Ponta Grossa, Porto Alegre, Rio Grande do Sul. Rev Bras Farmacogn 15: 361-372.

WHO 1999. Monographs on selected medicinal plants. Vol. 1. 


\begin{tabular}{|c|c|c|}
\hline $\begin{array}{l}\text { FAMILY } \\
\text { Scientific name } \\
\text { Popular name(s) }\end{array}$ & Part used & Indication and form of use \\
\hline ALISMATACEAE & & \\
\hline $\begin{array}{l}\text { Echinodorus grandiflorus (Cham. \& Schltdl.) Micheli } \\
\text { Aguapé, congonha-do-brejo }\end{array}$ & Leaves & $\begin{array}{l}\text { A cup of decoction after meals as diuretic and } \\
\text { against liver diseases. The topical use or as poultice } \\
\text { against rheumatism and arthritis. }\end{array}$ \\
\hline $\begin{array}{l}\text { ACANTHACEAE } \\
* \text { Justicia pectoralis Jacq. } \\
\text { Chambá }\end{array}$ & Leaves & $\begin{array}{l}\text { The syrup is used against asthmas, tosses, } \\
\text { bronchitis and as expectorant. }\end{array}$ \\
\hline
\end{tabular}

\section{ALOACEAE \\ *Aloe soccotrina $\mathrm{DC}$ Leaves \\ Babosa}

\section{AMARANTHACEAE}

Alternanthera brasiliana (L.) Kuntze

Acônito, ervanço, quebra-panela, perpétua-do-mato, acônito-do-mato, terramicina, tetrex

Alternanthera pungens Humb.

Periquito-de-espinho, carrapicho

Alternanthera tenella Colla
Corrente, quebra-panela

Amaranthus spinosus L.

Caruru-de-espinho, bredo-de-espinho

Amaranthus viridis $\mathrm{L}$.

Bredo, caruru-miúdo, bredo-de-porco, caruru-verde

*Celosia argentea $\mathrm{L}$.

Crista-de-galo

Gomphrena demissa Mart.

Capitãozinho, ervanço

*Gomphrena globosa L.

Perpétua, suspiro-branco

Gomphrena vaga Mart.

Capitãozinho

*Pfaffia glomerata (Spreng.) Pedersen

Acônito-bravo, anador

\section{AMARYLLIDACEAE}

Hippeastrum psittacinum (Ker Gawl.) Herb.

Alho-bravo, alho-do-mato, açucena-do-campo

\section{ANACARDIACEAE}

Anacardium humile A.St.-Hil.

Cajuí, cajuzinho

Anacardium occidentale $\mathrm{L}$.

Caju, cajueiro

Leaves

Roots

Leaves

Seeds

Roots

Leaves

Flowers

Roots

Leaves

Bulbs

Fruit
Inflorescences Treatment of colds and grippes, headaches and as

Aerial parts

Inflorescences

Fresh leaves

Leaves and roots

Fresh leaves

Entire plant

Entire plant

Leaves and flowers An infusion of a handful is used against fevers,

grippes and headaches.

Fruit, pseudofruit

Pseudofruit

Stem-bark

Resin

It is used as suppositories against hemorrhoids. The juice is indicated against leukemia, tuberculosis, prostate diseases, sinusitis, inflammations of uterus and ovaries. expectorant used as an infusion.

An infusion as antipyretic.

A decoction of fresh roots against diarrheas.

An infusion of a handful of fresh plant in a liter of water against grippes, headaches and abdominal pains.

A decoction of a spoonful in a cup of water as vermifuge. It is used before breakfast.

An infusion of a spoonful in a cup of water as diuretic, antipyretic and antiseptic of the tract urinary and against grippes.

An infusion as laxative and also indicated against venereal diseases and urinary inflammations.

Grounded and applied as a poultice over the skin or as decoction for baths as emollient against eczemas. The infusion as anti-inflammatory of the tract urinary and venereal diseases. The juice as vermifuge and it is drunk before breakfast.

A decoction of a handful in a liter of water against hydropsias. It is used as tea.

A decoction as vermifuge and anti-diarrheic. It is usead as tea.

A decoction of handful of roots in a liter of water for the treatment of female sterility, amenorrhea, inflammations and ovarian diseases.

As syrup as expectorant.

An infusion is used as hypertensive.

An infusion. It is used as analgesic for toothache. An infusion against asthmas and allergies.

The same recipe as above as anti-inflammatory of ovaries. It is drunk "as water" until symptoms disappear.

The infusion as aphrodisiac and as syrup it is purgative. The syrup as expectorant and against bronchitis and tosses.

The same indications and uses as Anacardium occidentale $\mathrm{L}$.

In nature are used as food against anemia and as tonic.

The juice is indicated against anemia and diabetes. The external use against burnings and ulcers.

The decoction is used as bath against vaginal and external ulcers. The internal use is indicated against diarrheas.

The topical use is indicated against warts coughs and wounds. 
Astronium fraxinifolium Schott ex Spreng.

Gonçalo-alves

*Mangifera indica $\mathrm{L}$.

Manga-espada, mangueira, manga

Myracrodruon urundeuva Alemão

Aroeira, aroeira-do-sertão

Schinopsis brasiliensis Engl.

Braúna

Schinus terebinthifolius Raddi

Aroeira-da-praia

*Spondias mombin $\mathrm{L}$

Cajá, taperebá

*Spondias purpurea L.

Siriguela

Spondias tuberosa Arruda

Imbuzeiro, umbuzeiro

Tapirira guianensis Aubl.

Pau-pombo, fruta-de-pombo

\section{ANNONACEAE}

Annona glabra $\mathrm{L}$.

Araticum, araticum do brejo

*Annona montana Macfad.

Graviola, araticum-grande, jaca-do-pará

*Annona squamosa $\mathrm{L}$.

Pinha, ata, fruta-de-conde

Duguetia furfuracea (A.St.-Hil.) Saff.

Araticum-cagão

Rollinia leptopetala R.E.Fr

Pinha-brava

Xylopia frutescens Aubl.

Embira, semente-de-embira

APIACEAE

*Coriandrum sativum L.

Coentro

*Foeniculum vulgare Mill.

Endro, funcho

*Pimpinella anisum L.

Erva-doce

APOCYNACEAE

Allamanda blanchetii A.DC.

Quatro-patacas-roxa, leiteiro.
Stem-bark

Resin and stem-

bark

Leaves

Stem-bark

Leaves

Stem-bark and

leaves

Leaves

Leaves

Stem-bark

Fruits

Stem-bark

Leaves

Leaves

Seeds

Stem-bark

Stem-bark

Stem-bark

Seeds and fruits

Leaves

Fruits

Fruits and leaves

Fruits

Latex
The use topic against calluses. The juice against toothaches.

The decoction as stomachic, anti-diarrheic and against genito-urinary inflammations, bronchitis and asthmas. The external use in baths or washes against scabies and syphilis.

In inflammations of ovaries. A decoction or maceration of a handful in a liter of water. It is drunk "as water". Against external ulcers. The same recipe as above. It is used to wash the ulcerative affections. This species has many other medicinal indication.

As antitussive and against diarrhea and dysenteries. A decoction of handful in a liter of water and sugar as syrup. A spoonful is drunk three to four times until the symptoms disappear.

A decoction of a handful in a liter of water. It is drunk as tea.

The same indications and uses as Myracrodruon urundeuva.

The decoction against diarrheas.

The same use and indication as above.

As ophthalmic. A decoction of a cup in a liter of water. It is used as wash for the infected eyes. Also used as digestive and laxative.

As tonic general and as source of vitamins It is drunk as juice of mature fruits or as a regional drink called "umbuzada", which is made with the green fruits, boiled and mashed and mixed with milk and sugar.

It is used as decoction against diarrheas.

The decoction is used against rheumatism. As vermifuge, it is used before the breakfast.

The juice of fresh leaves against snake bite. The decoction is drunk as water against obesity for lost weight.

The juice of grounded seeds is used in baths against louses.

The same indication and use as above.

As digestive, a decoction of a teaspoon in a cup of water. It is drunk as tea after meals.

Against tumors and inflammations. The same recipe as above. It is used substituting the water.

As digestive, a decoction of a teaspoon in a cup of water. It is drunk as tea after meals

The topical use of the leaves is indicated in treatment of contuses.

The decoction is used as digestive and against gastritis, constipations and anorexia.

The decoction on infusion as digestive and against menstrual spasms. An infusion of a teaspoon in a cup of hot water.

As emenagogue and digestive against intestinal pains and menstrual spasms

In treatment of amenorrhea. A decoction of a teaspoon in a cup of water. It is drunk until the menstruation appear.

It is used as laxative, emetic, cathartic and vermifuge. One teaspoon of the latex in a cup of water. It is drunk after meals.

It is referred to as poisonous. 
*Allamanda cathartica $\mathrm{L}$.

Dedal-de-dama

*Allamanda violacea Gardner \& Fielding

Rosa-mole

Asclepias curassavica $\mathrm{L}$.

Leiteira, oficial-de-sala

Aspidosperma pyrifolium Mart.

Pereiro, pau-pereiro

Calotropis procera (Aiton) W.T. Aiton Algodão-deseda,algodão-da-praia, flor-de-seda, flor-de-cera

*Catharanthus roseus (L.) G. Don

Boa-noite, boa-noite-branca

Hancornia speciosa Gomes

Mangabeira, mangaba

Himatanthus articulatus (Vahl) Woodson

Janaúba

Himatanthus bracteatus (A.DC.) Woodson

Janaguba

Himatanthus phagedaenicus (Mart.) Woodson

Banana-de-papagaio, angélica-da-mata

Mandevilla illustris (Vell.) Woodson

Purga-do-campo

Marsdenia altissima (Jacq.) Dugand

Cipó-seda

Marsdenia molissima E.Fourn

Maria-da-costa

*Nerium oleander $\mathrm{L}$.

Espirradeira

*Plumeria rubra $\mathrm{L}$

Jasmim

Rauvolfia grandiflora Mart. ex A. DC.

Mamão-de-sapo

Rauvolfia ligustrina Willd. ex Roem. \& Schult.

Arrebenta-boi

Schubertia grandiflora Mart. \& Zucc.

Maria-da-costa

Schubertia multiflora Mart.

Maria-da-costa

*Tabernaemontana divaricata (L.) R. Br. ex Roem. \&

Schult.

Jasmim

Tabernaemontana $\mathrm{sp}$.

Jasmim-bravo

*Thevetia peruviana (Pers.) K. Schum.

Chapéu-de-napoleão

ARACEAE

Caladium bicolor (Aiton) Vent.

Tajá

ARECACEAE

Acrocomia aculeata (Jacq.)Lodd. ex Mart.

Macaúba, macaíba

Astrocaryum vulgare Mart.

Tucum, tucumã, tucum-bravo
Entire plant

Entire plant

Entire plant

Stem-bark

Entire plant

Stem-bark

Latex

Latex

Leaves

Leaves, flowers, roots

Latex

Stem-bark

Latex

Latex

Latex

Green fruit

Latex

Stem-bark

Roots

Entire plant

Latex

Stem-bark

Flowers

Entire plant

Entire plant

Tuber

Tuber

Entire plant

Stem-bark

Latex

Roots

Entire plant

Leaves

Leaves

Fruit
As poisonous

As poisonous

As poisonous.

Against inflammations of urinary tract. A decoction of a teaspoon in a cup of water. It is used as tea until the symptoms disappear. The same recipe as above. It is used in baths.

As poisonous.

Small pieces in maceration in a liter of water. It is used as tonic and stimulant.

The topical use as odontalgic.

Dorpped in water as vermifuge.

The decoction against rheumatism and asthmas and as sedative.

Small pieces in maceration in a liter of water against diabetes and tuberculosis and as expectorant.

Dropped in water against tuberculosis and cramps. In maceration against respiratory diseases.

The topical use against external ulcers and tumors. Dropped in a liter of water against inflammations and cancer.

The same indication and use as above.

The topical uses against external ulcers.

Small pieces in maceration in a liter of water. It is used as water against diabetes and inflammations.

Some latex is dropped in a cup of water and drunk aganst liver diseases.

A maceration against gonorrhea, asthmas and cancer. It is used to increase the fertility.

As abortive and against amenorrhea. A decoction of a handful in a liter of water. It is drunk substituting the water until the menstruation appear.

As poisonous.

The topical use against dermatitis.

The decoction of a handful in a liter as vermifuge.

The syrup as expectorant.

As poisonous.

As poisonous.

A decoction as emenagogue and abortive.

The same indication and use as above.

As poisonous.

The decoction of a handful in a liter of water or in maceration in wine against syphilis.

The topical use against warts.

The decoction or syrup as expectorant.

As poisonous.

The decoction as vermifuge and purgative. The external use against furunculous.

A decoction against hypertension.

As food and source of vitamin A.

In nature as food. It is used as source of vitamin A. 
*Cocos nucifera L.

Coco, coqueiro

Copernicia prunifera (Mill.) H.E.Moore

Carnaubeira, carnaúba

*Elaeis guineensis Jacq.

Dendê, dendezeiro, azeite-de-dendê

Euterpe oleracea Mart.

Jussara, açaí

Mauritia flexuosa $\mathrm{L}$.

Buriti

Mauritiella aculeata (Kunth) Burret Buritirana

Orbignya phalerata Mart.

Babaçu

Polyandrococos caudescens (Mart.) Barb. Rodr.

Buri

\section{ARISTOLOCHIACEAE}

Aristolochia birostris Duch.

Jarrinha, angelicó

Aristolochia papillaris Mart.

Jarrinha, angelicó

\section{ASTERACEAE}

4canthospermum australe (Loefl.) Kuntze

Juiz-de-paz, espinho-de-judeu, carrapicho, espinho-de-

sigano

Acmella uliginosa (Sw.)Cass.

Agrião, agrião-bravo

4canthospermum hispidum DC.

Espinho-de-judeu, carrapicho, espinho-de-cigano, retirante

Ageratum conyzoides L.

Mentrasto, mentrasto-branco

Artemisia absinthium L.

Losna, absinto, erva-dos-vermes

*Artemisia vulgaris L.

Artemijo, flor-de-são-joão

Baccharis trimera DC.

Carqueja

Bidens bipinnata $\mathrm{L}$.

Picão, fura-capa, agulha-brava

Bidens pilosa L.

Carrapicho, picão, agulha-brava, picão-preto, carrapichode-agulha

Blainvillea acmella (L.) Philipson

Agrião

Chresta martii (DC.) H.Rob.

Chico-rodrigues
Roots

Entire plant

Leaves

Entire plant

Aerial parts

Fruit pulp

Roots

Oil of fruits

Fruits

Leaves

Fruits

Fruits

Young fruits, leaves and roots

Roots

Fresh plant

Roots

Entire plant

Leaves

Leaves

Entire plant

Entire plant

Leaves

Leaves

Roots

Leaves and roots

Entire plant

Flowers

Leaves
As laxative. The oil extracted by heat is emollient. It is used as tonic and hydrating against diarrheas, dysenteries and as diuretic.

A handful in a liter of water in maceration as depurative and diuretic The topical use against external ulcers, dermatitis, rheumatism and arthritis.

The topical use on skin as emollient.

The juice is drunk as general tonic.

The topica use as emollient.

Used in sweets and ice cream as source of vitamin A.

The same indication and use as above.

Against abdominal pains, constipation, obesities, leukemia, rheumatisms, inflammations of uterus and ovaries, arthritis and menstrual pains.

A maceration in a liter of water against diabetes and to reduce the cholesterol levels. It is drunk substituting the water.

As abortive and in treatment of amenorrhea. A decoction of a handful in a liter of water. It is drunk substituting the water until the menstruation appear.

The juice is used against snake bite

The same uses and indications as $A$. birostris.

As used for children diseases.

As tonic against anemia and as expectorant. It is eaten as salad. Also, it is prepared as syrup. Four spoonfuls is drunk by day until the symptoms disappear.

Used as anesthesic local against tooth pains.

A decoction of a handful in two parts of water against bronchitis and fevers and as expectorant. It is drunk as tea.

As vermifuge and against intestinal pains. The fresh plant is drunk as juice just once a day before the breakfast.

A decoction against ovarian inflammations, amenorrhea, dysmenorrheal, rheumatism and diarrheas.

An infusion as stomachic, against intestinal pains, anorexia and arthritis.

A juice of fresh plant is used as vermifuge and abortive and against gripes.

To chew against halitosis.

A decoction against dysmenorrheal, diarrheas, epilepsies and gastritis.

An infusion or decoction as digestive and against diabetes and renal inflammations.

An infusion is used to reduce the weight.

A decoction of a spoonful in a litter of water as diuretic.

An decoction or an infusion against blenorragias, furunculous and ictericias.

The same indication and uses as above.

It used as food in salad against anemia.

The topical use of the smashed flowers against toothaches.

An infusion is used against hepatic diseases and also malaria. 
Conocliniopsis prasiifolia (DC.) R.M.King \& H.Rob. Aleluia

Conyza bonariensis (L.) Cronquist

Rabo-de-raposa

*Dendranthema grandiflorum (Ramat.) Kitam.

Crisântemo

Eclipta prostrata $($ L.) L.

Agrião, perpétua-do-mato, Agrião-do-brejo, erva-de-botão

Egletes viscosa (L.) Less.

Macela-do-campo, macela, macela-da-terra

Emilia fosbergii Nicolson

Pincel, serralha

Emilia sonchifolia (L.) DC.

Pincel

Flaveria bidentis (L.) Kuntze

Contra-erva-do-peru

Galinsoga parviflora Cav.

Botão-de-ouro, picão, fazendeiro

*Gymnanthemum amygdalinum (Delile) Sch. Bip. ex

Walp.

Alumã, boldo

Hebeclinium macrophyllum (L.) DC.

Desinchadeira-de-cacau

* Helianthus annuus L.

Girassol

*Lactuca sativa $\mathrm{L}$.

Alface

Lepidaploa chalybaea (Mart. ex DC.) H.Rob.

Ervanço

Lourteigia ballotifolia (Kunth) R.M. King \& H. Rob.

Aleluia

Melampodium divaricatum (Rich.) DC.

Picão-da-praia

Mikania hirsutissima DC.

Cipó cabeludo

Pectis elongata Kunth

Alecrim-do-mato, alecrim-bravo,

cuminho-bravo

Pectis linifolia L. var. linifolia

Alecrim-do-mato

Pectis oligocephala (Gardner) Sch.Bip.

Alecrim-do-mato, caminho-do-mato

Pluchea sagittalis (Lam.) Cabrera

Quitoco, madrecravo
Aerial parts

Entire plant

Leaves

Inflorescence

Leaves

Inflorescences

Inflorescences and leaves

Leaves and entire

plant

Entire plant

Inflorescence

Entire plant

Leaves

Leaves

Seeds

Leaves

Leaves

Leaves

Entire plant

Entire plant

Entire plant

Entire plant

Entire plant

Leaves

An infusion is prepared with a handful of fresh plant in a liter of hot water. It is drunk as tea against grippes and colds. The same preparation boiled with sugar as syrup. Three spoonfuls daily until symptoms disappear.

A decoction is used against dermatitis.

An infusion or decoction of a handful in a liter of water as stomachic. It is drunk as tea after meals, until the symptoms disappear.

A decoction or an infusion against edemas.

As anti-asthmatic and against hepatitis and liver diseases. An infusion or a decoction is of handful in a liter. It is used as tea until symptoms disappear. External ulcers. A handful is powdered and applied over the affected skin.

As stomachic and against diarrheas and insomnias. A handful of inflorescences in a liter of water as infusion or decoction. It is drunk as tea after meals until symptoms disappear.

The infusion of a handful is used against fevers and diarrheas.

The same use and indication as above.

The decoction against verminosis. It is used before breakfast.

Against grippes and colds. An infusion of a handful in a liter of water. It is drunk as tea until the symptoms disappear.

A decoction of a handful in a liter against fevers, constipation and abdominal pains.

It is used as poultice against hurt in the foot.

In nature as food against cholesterol. An infusion of the roasted and grounded seeds as "café" against fevers.

The topical use as poultice against ulcers and hurts. An infusion of two leaves in a cup of water against hypertension and insomnias.

The decoction of a handful in a liter. It is used for hairs washes or in baths against dandruffs.

Against grippes and colds. An infusion is prepared with a handful of fresh plant in a liter of hot water. It is drunk as tea. The same preparation boiled with sugar as syrup. Three spoonfuls daily until symptoms disappear.

A decoction or infusion as diuretic and against leucorrhoea.

A decoction or infusion against diarrheas, rheumatism, neuralgias, nephrites and paralysis.

Against hypotension and stomachic diseases, an infusion with two parts of water. It is drunk cold substituting the water until symptoms disappear.

As stomachic, the same recipe as above. It is drunk as tea after meals.

Against grippes and colds, an infusion of a spoonful in a glass of water. It is drunk until symptoms disappear.

Leaves and entire The same indications, preparations and uses as plant

Aerial parts above.

Against grippes and colds, an infusion of a spoonful in a glass of water. It is drunk until symptoms disappear.

Inflorescence A decoction as stomachic and against hypertension.

Entire plant The infusion as digestive and stomachic and expectorant against tosses bronchitis. It is used to facilitate the childbirth. 
Porophylum ruderale (Jack) Cass.

Cravo-de-urubu, couvinha

Sonchus oleraceus L.

Alface-do-mato, barbalha, serralha-lisa

Sphagneticola trilobata (L.) Pruski

Mal-me-quer, camará

*Tagetes erecta

Cravo-de-defunto

Tagetes minuta $\mathrm{L}$.

Coari-bravo, cravo-de-viúva, cravo-bravo

*Tanacetum vulgare L.

Erva-dos-vermes, ervas-de-são-marcos

Trixis divaricata (Kunth) Spreng.

Selidônea, sete-sangrias

Trixis vauthieri DC.

Sete-sangrias

Unxia suffruticosa (Baker) Stuessy Mal-me-quer-do-sertão

Verbesina macrophylla (Cass.) S.F. Blake

Assa-peixe

\section{BIGNONACEAE}

Anemopaegma laeve DC.

Catuaba

Crescentia cujete L.

Cuité, cabaço, coite, cueira, cuia, cuieira

Jacaranda brasiliana (Lam.) Pers.

Caroba-branca

Jacaranda caroba (Vell) A.DC.

Caroba-preta

Melloa quadrivalvis (Jacq.) A.H.Gentry

Cipó-de-cesta

Mansoa hirsuta DC.

Alho-bravo, cipó-de-alho

Pyrostegia venusta (Ker Gawl.) Miers

Cipó-de-são-joão, flor-de-são-joão, cipo-de-cesto, cipó-de-

fogo, cipó-de-lagartixa, cipó-pé-de-lagartixa, cipó-de-

lagarto, cipó-catitu,

Tabebuia aurea (Silva-Manso) Benth. \& Hook.f. ex S.

Moore

Craibeira

Tabebuia avellanedae Lorentz ex Griseb.

Pau-d'arco-roxo, ipê-roxo

Tabebuia impetiginosa (Mart. ex DC.) Standl.

Pau-d'arco

Tabebuia serratifolia (Vahl) G.Nicholson

Pau d'arco amarelo

Tabebuia spongiosa Rizzini
Leaves

Leaves

Entire plant

Flowers

Flowers

In uterine and testicular inflammations and against fevers. An infusion or decoction of a spoonful in a glass of water. It is drunk as tea until the symptoms disappear.

As sedative. The same recipe as above. A cup is drunk as tea at night before sleep.

As tonic, stomachic and preventive of cardiovascular diseases and against hepatitis. A decoction of a spoonful in a glass of water. It is drunk as tea until the symptoms disappear.

Flowers and Against grippes, colds and pneumonias. An

Leaves infusion is prepared with a teaspoon in a cup of hot water. It is drunk as tea.

Flowers and leaves An infusion of a handful in a liter. It is used against asthmas.

Leaves

Against evers, amenorrhea and as sedative.An infusion or decoction in two parts of water. It is drunk as tea before sleep.

Leaves

Inflorescence

As vermifuge. The same recipe as above. It is drunk only once a day.

Entire plant

A decoction as vermifuge.

As abortive and against amenorrhea. A decoction of a handful in a liter of water. It is drunk substituting the water until the menstruation appears. It is also used for wash the eyes against conjunctivitis.

The same uses and indications as above.

Against grippes and colds. An infusion is prepared with a teaspoon in a cup of hot water. It is drunk as tea.

An infusion or decoction are used against inflammations.

Roots and stem-

bark

Leaves

Seeds

Stem-bark

Leaves

Entire plant

Leaves

Stem-bark

Leaves

Roots

Stem-bark

Stem-bark

Stem-bark

Stem-bark

Stem-bark
A decoction or a maceration in water or wine or "cachaça" as aphrodisiac.

The infusion or decoction as diuretic. Against genitourinary diseases.

A decoction against syphilis and diuretic. It is used as bath or washes.

An infusion in water or maceration in alcohol. The external uses against syphilis and ulcers.

As poisonous.

A decoction against diabetes. It is drunk 3 times daily.

A decoction against throat pains. It is used as gargling.

As poisonous.

The maceration is referred as tonic and against diarrheas.

Against grippes and bronchitis. A decoction of a handful in a liter of water. It is drunk as tea until the symptoms disappear. In maceration it is used substituting the water against general inflammations. Against cancer, liver diseases, inflammations of the skin, of the ear and the mucosa (gingival, throat, vagina, uterus and anus), ovaries and prostate and muscle. The maceration substituting the daily water.

The same indications and uses as above.

The same indications and uses as above.

The same indications and uses as Tabebuia impetiginosa. 
BIXACEAE

Bixa orellana $\mathrm{L}$.

Urucum, açafrão, açafroa

BOMBACACEAE
Ceiba glaziovii (Kuntze)K. Schum.
Barriguda
BORAGINACEAE
Cordia globosa (Jacq.) Kunth
Maria-preta, bamburral, pau-pretinho
Cordia leucocephala Moric.
Moleque-duro, negro-duro

Cordia multispicata Cham.

Maria-preta

Cordia piauiensis Fresenius

Grão-de-galo

Cordia polycephala (Lam.) I.M.Johnst.

Maria-preta

Cordia trichotoma (Vell.) Arráb. ex Steud.

Freijó, frei-jorge, cabo-de-machado

Heliotropium indicum $\mathrm{L}$.
Fedegoso, crista-de-galo

\section{BRASSICACEAE}

*Brassica integrifolia (H. West.) Rupr.

Mostarda

* Brassica oleracea var. acephala DC.

Couve

Lepidium bonariense $\mathrm{L}$.

Agrião-bravo

*Nasturtium officinale $\mathrm{R}$. Br.

Agrião, agrião-verdadeiro

\section{BROMELIACEAE}

Bromelia laciniosa Mart. ex Schult.f.

Macambira

Bromelia plumieri (E.Morren) L.B.Sm.

Caroá, banana-de-raposa

Tillandsia recurvata $(\mathrm{L}.) \mathrm{L}$.

Barba-de-velho $^{\mathrm{d}}$

Tillandsia streptocarpa (L.) Baker

Gravatá-do-ar

Tillandsia usneoides (L.) L.

Barba-de-velho

BURSERACEAE
Aril of seeds

\section{Roots}

Leaves

Leaves and stembark

Leaves

Leaves

Flowers

Aerial parts

Leaves and aerial

parts

Leaves

Leaves

Leaves and stembark

Aerial parts

Roots

Leaves

Roots

Leaves

Fruits

Entire plant

Entire plant

In maceration against bronchitis, and respiratory diseases. The topical uses as insect repellent and for child illness

As diuretic and against cardiac and vascular diseases.

A decoction is drunk against fatigues and hypertension.

Against rheumatism and edemas. A decoction of a handful in a liter of water. It is used in wash for the affected area until the symptoms disappear.

Against menstrual colic's. An infusion of a handful in a liter. It is drunk as tea

Against indigestions. A decoction of a handful in a glass of water. It is drunk as tea.

As general tonic. As syrup prepared with a cup of flowers and half liter of water. A spoonful of syrup is drunk during the meals.

Against rheumatism, arthritis and rickets.

The same recipe and use as above.

A decoction against rheumatism, arthritis and rickets.

The same recipe and use as C. Leucocephala.

Against kidney diseases, rheumatism, arthritis and rickets. A decoction of a handful in a liter of water. It is used until the symptoms disappear.

As diuretic and against hepatic diseases. An infusion of a handful in $1 / 2$ liter of water. It is drunk substituting the water.

Against conjunctivitis. The same recipe as above. It used cold to wash the eyes.

Against hepatic and renal diseases and as diuretic. A maceration of a handful in a liter of "cachaça". It is drunk before meals.

A decoction of a teaspoon in a cup of water. It is drunk "as water" against intestinal and stomachic diseases until the symptoms disappear.

Leaves

Leaves

Leaves

An infusion against stomachic diseases or as fresh juice. It is drunk a cup daily against osteoporosis. It is used as salad against anemia and tuberculosis.

The same use and indications as above.

A decoction of a handful in a liter of water is used against hepatitis, intestinal diseases and as diuretic. It is drunk "as water" until the symptoms disappear.

As source of protein, dried and powdered. It is eaten mixed with the meals.

As vermifuge. It is eaten before breakfast only once.

Against rheumatism, ulcers and hemorrhoids. A decoction of a small plant in a liter of water. It is used as tea once a day until the symptoms disappear. As purgative, laxative and emetic A decoction of $1 / 4$ of a plant in a liter of water. It is used as tea after meal until the symptoms disappear.

Entire plant A handful in a cup of water is used against hemorrhoids. 
Protium heptaphyllum (Aubl.) Marchand

Almécega, almiscar

Protium pallidum Cuatrec.

Breu-branco

Protium tenuifolium (Engl.) Engl.

Almiscar

\section{CACTACEAE}

Cereus jamacaru DC.

Mandacaru

Harrisia adscendens (Gürke) Britton \& Rose

Rabo-de-raposa

Melocactus zehntneri (Britton \& Rose) Luetzelb.

Coroa-de-frade, cabeça-de-frade

\section{CAPPARACEAE}

Capparis flexuosa (L.) L.

Feijão-bravo, feijão-de-boi

Capparis frondosa Jacq.

Feijão-bravo, feijão-de-boi

Capparis jacobinae Moric ex Eichler

Icó

Capparis yco Mart.

Feijão-bravo, feijão-de-boi, icó-preto

Crateva tapia $\mathrm{L}$.

Trapiá, tapiá, pau-d'alho

Cleome aculeata $\mathrm{L}$.

Xinxim-de-galinha

Cleome spinosa Jacq.

Muçambê

\section{CAPRIFOLIACEAE}

* Sambucus australis Cham. \& Schltdl.

Sabugueiro, flor-de-sabugueiro

\section{CARICACEAE}

*Carica papaya $\mathrm{L}$.

Mamão

Jacaratia dodecaphylla (Vell.) A. DC.

Jacaratiá

Jacaratia heptaphylla (Vell.) A.DC.

Jacaratiá

Jacaratia spinosa (Aubl.) A. DC.

Jacaratiá-de-espinho

\section{CARYOCARACEAE}

Resin

Stem-bark

Resin and

Stem-bark

Resin and

Stem-bark

Roots

Stem pulp

Roots

Stem pulp

Stem bark

Leaves

Roots

Stem-bark

Stem-bark

Roots

Stem-bark

and roots

Leaves

Fruits

Stem-bark

Entire plant

Leaves

Flowers

Flowers

Fruit

Leaves

Latex

Latex

Latex
In treatment of grippes, coughs, bronchitis, treat urinary and liver diseases. A decoction of a handful in a liter of water and made with sugar as syrup. A spoonful is drunk 5-6 times a day. The external use against ulcers in washes or baths against vaginal ulcers.

It is mixed and grounded with tobacco leaves. It is used as "rapé" (snuff) against sinusitis.

As syrup or decoction against tosses and bronchitis.

The same indications and uses as above.

The same uses and indications as P. Heptaphyllum.

Against respiratory and renal diseases, as diuretic. An infusion of a handful in a liter of water. It is drunk substituting the water until the symptoms disappear.

Against stomachic ulcers. It is mashed with sugar. A spoonful is drunk three times.

An infusion against amenorrhea and as diuretic and anti-inflammatory.

Treatment of bronchitis and coughs and in physical debility. As juice. It is drunk before meals.

Against coughs and whooping coughs. A decoction of a handful in a $1 / 2$ liter of water or added as syrup. It is drunk as tea or as syrup.

As emenagogue. The same recipe of decoction as above. It is drunk substituting the water.

The decoction is used as digestive. The same recipe as above.

Against coughs and whooping coughs. A decoction of a handful in a $1 / 2$ liter of water or added sugar as syrup. It is drunk as tea or as syrup.

As emenagogue. The same recipe of decoction as above. It is drunk substituting the water.

The same uses and indications as above.

The decoction as gargling against inflammations and irritations of the throat.

Eating as food is used as tonic and febrifuge.

A decoction as tonic and against fevers Externally in washes and baths against ulcers and nails illness. The infusion against kidney diseases and obesity.

Against asthmas, coughs and bronchitis. An infusion of a spoonful in a cup of water or as syrup. It is drunk as tea or as syrup, a spoonful four times a day. Against fevers. The same recipe and use as above.

An infusion of a teaspoon in a cup of water. It is used against fevers, chickenpox and measles until the symptoms disappear.

It is used "in nature" as digestive, laxative and against high blood pressure.

An infusion is used as digestive

It is dropped in a cup of water and drunk as purgative and against intestinal worms.

The same uses and recipe as above.

The same uses and recipe as above. 
Caryocar brasiliense Cambess.

Piquí

Leaves

Fruit

Caryocar coriaceum Wittm.

Piquí

Caryocar cuneatum Wittm.

Piquí

\section{CECROPIACEAE}

Cecropia hololeuca Miq.

Embaúba, imbaúba

Cecropia obtusa Trécul

Imbaúba

Cecropia palmata Willd.

Torém, imbaúba

Cecropia peltata $\mathrm{L}$.

Imbaúba, simbaúba

\section{CELASTRACEAE}

Maytenus obtusifolia Mart.

Carrancudo

Maytenus rigida Mart.

Bom-nome

\section{CHENOPODIACEAE}

*Beta vulgaris $\mathrm{L}$.

Beterraba

Chenopodium ambrosioides $\mathrm{L}$.

Mastruço

\section{CHRYSOBALANACEAE}

Chysobalanus icaco L.

Guajerú, guajiru

Licania rigida Benth.

Oiticica

\section{CLUSIACEAE}

Platonia insignis Mart.

Bacuripari, Bacuri

Vismia guianensis (Aubl.) Pers.

Lacre

Vismia reichardtiana (Kuntze) Ewan

Lacre, lacre vermelho

COMBRETACEAE

Buchenavia tetraphylla (Aubl.) R.A.Howard

Caicaró

Combretum lanceolatum Pohl ex Eichler

Mofumbo-do-rio, mofumbo

Combretum leprosum Mart.

Mofumbo, mofumbo-branco, pente-de-macaco

*Terminalia catappa L.

Castanhola, amendoeira

Thiloa glaucocarpa (Mart.) Eichler

Sipaúba

\section{COMMELINACEAE}

Leaves

Fruit

Leaves

Fruit

A decoction against grippes and coughs.

The oil from fruits is used against rheumatism, external ulcers, muscle pains and inflammations.

The same uses and indications as above

The same uses and indications as $C$. Brasiliense.

Roots and/or

leaves

Leaves

Leaves

Leaves

Leaves

Stem-bark

Stem-bark

Tuber

Entire plant

Roots

Stem-bark

Leaves

Seeds

Stem-bark

Latex

Stem-bark

Stem-bark

Stem-bark and

leaves

Leaves

Fruits

Entire plant
The maceration or decoction of a handful in a liter of water and used against diabetes and as diuretic. It is drunk 3 times daily. The external use against furunculous

A maceration of a handful in a litter of water is indicated against diabetes. It is drunk as substituting water.

The infusion as stimulant, tonic and as diuretic.

The decoction against hart diseases and diabetes.

A decoction against general inflammations and cancer.

Grounded as powder it is used against external ulcers on the skin.

Against infections and inflammations of ovaries and kidneys and cancer. A decoction or infusion or maceration of a handful in a liter of water. It is drunk substituting the water. Against external cancer and ulcers. A decoction is prepared as above and used to wash the external affections.

It is used as syrup against grippes and as expectorant.

As vermifuge, stomachic and expectorant A juice of entire plant is extracted with milk. It is drunk before breakfast.

The maceration against diabetes and inflammations. It is drunk daily as water.

The decoction against diarrheas

Against diabetes. A handful in decoction in a liter of water. It is drunk substituting the water until the symptoms disappear.

The seed oil's against eczemas and herpes. The decoction against diarrheas.

The infusion or maceration as laxative and against dermatitis.

The topical use against furunculous. It is dropped in water and drunk as purgative.

An infusion as digestive. It is drunk after meals.

The same indications and uses as above.

As expectorant and against coughs and diarrheas. A decoction or syrup of a handful in $1 / 2$ liter of water. It is drunk as tea or as syrup four times a day.

The same indications and uses as above.

The nut is used as tonic against general weakness.

As poisonous. 
Commelina erecta L.

Erva-de-santa-luzia

Tradescantia zebrina Heynh.

Marianinha, Zebrina

\section{CONVOLVULACEAE}

Evolvulus gypsophiloides Moric.

Sete-sangrias

Ipomoea asarifolia (Desr.) Roem. \& Schult.

Salsa, salsa-do-rio

Ipomoea carnea subsp. fistulosa (Mart. ex

Choisy)D.F.Austin

Canudo-de-pito, canudo, mata-pinto

Ipomoea hederifolia $\mathrm{L}$.

Flor-de-cardeal, primavera

Ipomoea nil (L.) Roth

Campainha, flor-de-são-joão, Amarra-amarra, campainha, jitirana

Ipomoea pes-caprae (L.) R.Br.

Salsa-de-praia

Merremia dissecta (Jacq.) Hallier f.

Jitirana

Operculina hamiltonii (G.Don) D.F.Austin

Batata-de-purga

Operculina macrocarpa (L.) Urb.

Batata-de-purga, batatão, jalapa

COSTACEAE

Costus spiralis (Jacq.) Roscoe var. spiralis

Cana-de-macaco

CRASSULACEAE

Bryophyllum calycinum Salisb.

Folha-da-costa

* Kalanchoe brasiliensis

Coirama-branca

CUCURBITACEAE

*Citrullus lanatus (Thunb.) Matsum. \& Nakai

Melancia

*Cucumis anguria L.

Maxixe

*Cucumis sativus L.

Pepino

*Cucurbita pepo L.

Abóbora, jerimum

*Lagenaria siceraria (Molina) Standl.

Cabaça

Luffa operculata (L.) Cogn.

Cabacinha, buchinha
Fruit

Seeds

Leaves

Inflorescences

Entire plant

Entire plant

Leaves or aerial parts

Leaves

Leaves and aerial

parts

Roots

Roots

Entire plant

Leaves

Entire plant

Tubers

Tubers

Tubers and seeds

Tubers

Leaves

Leaves

Leaves

Fruit

Seeds

Fruit pulp

Fruits
Against conjunctivitis. The liquid from the floral spathes is dropped in the infected eyes.

The infusion is used as ophthalmic. It is dropped in infected eyes.

A decoction or infusion of a handful in a liter of water. It is used against litiasis renal.

Against dermatitis, scabies, syphilis, skin ulcers and external wounds. A decoction of a handful in a liter of water. It is used in baths or as washes in the parts affected.

As purgative. An infusion or decoction in a liter of water. It is drunk after meals.

Against dermatitis. A decoction of a handful in a liter of water. It is used to wash the parts affected.

Against rheumatism The same recipe as above. It is drunk as tea until the symptoms disappear.

As purgative. The same recipe and use as above.

Against dermatitis, scabies, syphilis, skin ulcers and external wounds. A decoction of a handful in a liter of water. It is used in baths or as washes in the parts affected.

An infusion of a teaspoon in one cup of water as sedative. It drunk before to sleep.

Known as poisonous.

Against bronchitis and coughs. As syrup made with a small piece and two cups of water. A spoonful is drunk four times a day.

Against rheumatism and as anti-inflammatory. A decoction or infusion is prepared with a "small piece" in two cups of water. It is drunk after meals. As laxative, purgative and carminative. The same recipe as above. It is drunk as tea after meals.

The same indications and as substitute of Operculina hamiltonii The same recipes and uses as above.

An infusion is used as diuretic.

The smashed leaves are used against gastritis, ulcers, tosses bronchitis and vesicular pains. The topical use against external ulcers. It also dropped against pain of ear.

The same indications and uses as above.

In nature as food as tonic and refreshing.

Roasted and grounded as "café" against amenorrhea and dysmenorrheal.

The topical use with hot butter or olive oil as emollient .

It is used as poultice to clear the skin.

Grounded with milk. It is drunk before the breakfast against verminosis.

The pulp is drunk against hidropisias.

Against amenorrhea. A decoction of $1 / 4$ of the fruit in a cup of water. It is drunk only once. Agains sinusitis, $\mathrm{n}$ the same recipe as above is dropped into the noses. 
Momordica charantia L.

Melão-de-sabiá, melão-de-são-caetano, galinha-de-melão

*Sechium edule (Jacq.) Sw.

Chuchu

Wilbrandia verticillata (Vell.) Cogn.

Cabeça-de-negro

\section{CYPERACEAE}

Rhynchospora nervosa (Vahl) Boeck.

Capim-estrela

ERYTHROXYLACEAE

Erythroxylum pungens O. E. Schulz,

Rompe-gibão, catuaba

\section{EUPHORBIACEAE}

Aleurites moluccanus (L.) Willd.

Nogueira, nogueira-da-india, nogueira-de-bancul,

Nogueira-de-iguape.

Cnidoscolus infestus Pax. \& K.Hoffm.

Urtiga-de-boi

Cnidoscolus quercifolius Pohl

Favela, faveleiro, queimadeira

Cnidoscolus urens (L.) Arthur

Urtiga-branca, cansanção

Croton cajucara Benth.

Sacaca

Croton campestris A.St.-Hil

Velame-branco, velame

Croton moritibensis Baill.

Velame-preto

Croton muscicapa Müll.Arg.

Velame-de-cheiro

Croton pulegioides Baill.

Velame

Croton rhamnifolius Willd.

Alecrim-de-tabuleiro

Croton sonderianus Müll.Arg.

Marmeleiro, cansanção

Croton triqueter Lam.

Malva-de-cheiro

Croton zehntneri Pax \& K.Hoffm.

Canelinha, mulatinha

Dalechampia scandens L.

Urtiga-mamão

Euphorbia hirta L.

Erva-de-santa-luzia

Euphorbia hyssopifolia L.

Erva-de-leite, burra-leiteira

Euphorbia phosphorea Mart.

Cipó de fogo, pau de leite

*Euphorbia tirucalli L.

Avelós
Fruit

Leaves

Tuber

Entire plant

Stem-bark

Roots

Stem-bark

Stem-bark

Latex

Stem-bark

Roots

Leaves

Roots and leaves

Roots and leaves

Leaves

Leaves

Leaves

Entire plant

Entire plant

Leaves

Entire plant

Entire plant

Leaves and aerial

part

Latex and leaves

Latex

Entire plant

Latex

Latex

Roots
As anti-diabetic and vermifuge and against rheumatisms and diarrheas. A decoction of a handful in a liter of water. It is drunk as tea, until the symptoms disappear. Against dandruff. A decoction of a handful in a liter of water. It is used to wash the hair until dandruff disappear

As juice mixed with orange juice is drunk against hypertension.

An infusion as hypotensive.

A decoction, syrup or as maceration of a handful in

a liter. It is drunk as purgative and depurative against syphilis and furunculosis.

The decoction of a handful in a liter of water. It is used against inflammations and venereal diseases.

A maceration in water or cachaça as aphrodisiac. It is drunk before meals.

Against urinary and ovarian inflammations. A handful as decoction in a liter of water. It is drunk substituting the water until the symptoms disappear.

As anti-inflammatory of the ovaries and prostates. A decoction of a handful in a liter of water. It is drunk substituting the water until the symptoms disappear.

As anti-inflammatory of the ovaries and prostates. A decoction of a handful in a liter of water. It is drunk substituting the water until the symptoms disappear.

Against external ulcers.

As anti-inflammatory of the ovaries and prostates A decoction of a handful in a liter of water. It is drunk substituting the water until the symptoms disappear.

A decoction against external ulcers, eczemas and syphilis. It is used as bath.

A decoction against rheumatism and appendicitis.

A decoction against external ulcers, eczemas and syphilis. It is used as bath.

The same indications and uses as above.

A decoction as antiseptic against dermatitis.

A decoction against grippes, bronchitis and as expectorant.

A decoction against intestinal pains, grippes, asthmas and bronchitis.

The external use against scabies and as haemostatic.

The same uses and indications as above.

A infusion or decoction is used as tea against diarrheas and dysenteries.

The same uses and indications as C. rhamnifolius.

As toxic and provokes allergies.

A decoction as purgative and against hemorrhages, asthmas and bronchitis.

As juice against snake bite.

It is dropped in skin against conjunctivitis and in external ulcers.

As decoction against tosses.

It is used to cauterize warts.

Against external ulcers and to cauterize warts.

A decoction as purgative. 
*Jatropha curcas L.

Pinhão

Jatropha molissima (Pohl)Baill.

Pinhão-bravo, pinhão-manso

Jatropha ribifolia (Pohl)Baill.

Pinhão-de-purga

Manihot glaziovii Müll. Arg.

Maniçoba

* Manihot esculenta Crantz

Aipim, macacheira, mandioca, mandioca-branca,

mandioca-roxa, maniva

Maprounea guianensis Aubl.

Ricinus communis L.

Rícino, mamona

Sapium argutum (Müll. Arg.) Huber

Pau-de-leite, pau-de-candeia, burra-leiteira

Sapium sellowianum (Müll. Arg.) Klotzsch ex Baill.

Burra-leiteira

Sebastiania brasiliensis Spreng.

Purga-de-leite

Tragia volubilis L.

Urtiga-de-rama, cansanção

FABACEAE-CAESALPINIOIDEAE

Bauhinia cheilantha (Bong.)Steud

Mororó, pata-de-vaca

Bauhinia forficata Link

Mororó, pata-de-vaca

Bauhinia longifolia D.Dietr.

Unha-de-vaca, pata-de-vaca

Bauhinia macrostachya Benth.

Pata de vaca, pé-de-boi, mororó-da-catinga

*Bauhinia monandra Kurz

Mororó

Bauhinia pentandra (Bong.)Vogel ex Steud

Mororó-de-espinho

Mororó-de-rama

Caesalpinia bracteosa Tul.

Catingueira, pau-de-rato, pau-santo

Caesalpinia echinata Lam.

Pau-brasil

Caesalpinia ferrea Mart.

Pau-ferro, jucá

Caesalpinia microphylla Mart. ex G.Don

Arranca-estribo

Caesalpinia pyramidalis Tul.

Catingueira
Bauhinia pulchella Benth.
Latex

Seeds

Latex

Leaves

Latex

Leaves

Starch

Stem-root

Seeds

Stem-bark

Stem-bark

Stem-bark

Latex

Entire plant

Leaves

Leaves

Leaves

Stem-bark

Stem-bark

Stem-bark

Flowers, fruits and stem-bark

Stem-bark

Stem-bark

Epicarp

Stem-bark

Stem-bark

Stem-bark or resin
To treat snake bites. The latex is drunk directly from the stems.

As veterinary vermifuge. The oil is extracted from seeds. A spoonful is used only once.

To treat snake bites.

The same recipe and use as above

Against rheumatisms. It is used as poultice above painful part.

It is used against snake bite.

The topical use of the decoction against hemorrhoids.

The topical use as powder against babies rashes.

The infusion of a small piece against anorexia. As poisonous

The oil from seeds is used as purgative.

A decoction as abortive and purgative. The external use against ulcers.

The same use and recipe as above.

A decoction is drunk against amenorrhea, leucorrhoea and as purgative and diuretic. The topical use against dermatitis, eczema, hidropsias and syphilis.

The same indications as above.

The decoction is drunk as diuretic.

As a tonic and depurative and against diabetes. An infusion or decoction of a handful in a liter of water. It is drunk during the meals until the symptoms disappear.

The same uses and indications as above.

The same uses and indications as B. cheilanta.

Against diabetes. An infusion or a decoction of a handful in a liter of water. It is drunk before meals. The same uses and indications as B. cheilanta.

The same uses and indications as $B$. cheilanta.

The same uses and indications as $B$. cheilanta.

The decoction of a handful in a liter of water as tonic.

The decoction against external ulcers. It is drunk as tonic.

A decoction or as "garrafada" against anemia, diarrheas and dysenteries.

The syrup is drunk against tosses and anemia.

The decoction is drunk as digestive and sedative.

As aphrodisiac. A maceration of a handful in a liter of wine or "cachaça". It is drunk before the meals two times a day. Against dysenteries, diarrheas and stomachache. A decoction of one part in two parts of water. It is drunk as tea until the symptoms disappear.

As an expectorant and used against bronchitis, coughs and respiratory infections. A decoction with sugar as syrup. A spoonful of the syrup is drunk four to five times a day

Cenostigma gardnerianum Tul.

Canela-de-velho 
Copaifera multijuga Hayne

Copaíba

Copaifera reticulata Ducke

Copaíba

Dimorphandra gardneriana Tul.

Fava d'anta

Diptychandra aurantiaca subsp. epunctata (Tul.) Lima, Stem-bark

Carvalho \& Costa ex G. P. Lewis

Hymenaea courbaril L.

Jatobá

Hymenaea intermedia Ducke

Jutaí

Hymenaea martiana Hayne

Jatobá

Hymenaea oblongifolia Huber

Jatobá

Hymenaea parvifolia Huber

Jutaí do campo

Hymenaea stigonocarpa Mart. ex Hayne

Jatobá, jatobá-da-casca-fina

Pakinsonia aculeata L.

Turco, tangerim

Oil

Entire plant

Fruits

Stem-bark

Resin

Epicarp

Stem-bark

Epicarp

Stem-bark

Epicarp

Stem-bark

Epicarp

Stem-bark

Epicarp

Stem-bark

Epicarp

Seeds
Leaves

Senna alata (L.) Roxb.

Mangerioba-grande
Senna martiana (Benth.) H.S.Irwin \& Barneby

Canafístula, café-bravo

Senna obtusifolia (L.) H.S.Irwin \& Barneby

Mata-pasto, fedegoso

Senna occidentalis (L.)Link

Fedegoso, mata-pasto

Senna spectabilis var. excelsa (Schrad.)H.S.Irwin \&

Barneby

Canafístula

Leaves

Leaves

Seeds

Leaves

Seeds

Stem-bark

Leaves

Roots

Seeds

Leaves

Bark

Senna velutina (Vogel) H.S.Irwin \& Barneby

São-joão

*Tamarindus indica $\mathrm{L}$.

Tamarindo

FABACEAE-FABOIDEAE

Amburana cearensis (Allemão)A.C.Sm.

Amburana, cumarú, umburana-de-cheiro, amburana, umburana

Leaves

Fruit

Stem-bark
The oil extracted from the plant is used against cancer and general inflammations.

The same uses and indications as above.

A decoction against hemorrhoids, varicose veins, haematom and vascular diseases.

A decoction is drunk as purgative.

A decoction or as syrup. It is drunk against tosses and anemia.

It is used against sinusitis and abdominal spasms.

The syrup is drunk as tonic against anemia

The same uses and indications as above.

The same uses and indications as $H$. courbaril.

The same uses and indications as $H$. courbaril.

The same uses and indications as $H$. courbaril.

The same uses and indications as $H$. courbaril.

Against fevers and malaria. The seeds are roasted, powdered, and prepared as coffee and drunk as tea until the symptoms disappear. As antiepileptic and febrifuge. As infusion or decoction of a handful in a liter of water. It is drunk as tea. Against snakebite. A decoction of a handful in a liter of water. It is drunk substituting the water.

The decoction against scabies, herpes and dermatitis.

An infusion of a handful in two cups of water as laxative and abortive. It is drunk until the symptoms disappear.

The infusion is indicated as abortive and laxative. Against amenorrhea and rheumatism also.

An infusion of a teaspoon in a cup of water as sedative.

A decoction of a spoonful in a cup of water is used as a general tonic.

Roasted and powdered is prepared as coffee. It is drunk as tonic for memory A cup is drunk after meals until the symptoms disappear.

Against grippes and colds. A decoction of a spoonful in a cup of water. It is drunk as tea or as syrup four times a day.

As a laxative and purgative. The same recipe as above. It is drunk as tea.

Against amenorrhea. The same recipe and use as above.

Against anemia. It is Roasted and powdered and is prepared as coffee. A cup is drunk after meals until the symptoms disappear.

An infusion is indicated against intestinal diseases and as laxative.

The external use of a decoction against dermatitis.

The decoction of a handful in a liter. It is used against toothaches and kidney diseases.

The juice or pulp is used as laxative

In treatment of grippes, coughs and bronchitis. A decoction of a handful in two parts of water made as syrup. A spoonful of it is drunk four to six times a day.

Stem-bark As tonic in anorexia. The same recipe and use as above.

Stem-bark or seeds Against external ulcers. The dried stem-bark is grounded as powder. It is applied on the part 
Stem-bark

Bowdichia virgilioides Kunth

Sucupira-preta

*Cajanus cajan (L.) Millsp.

Guandu, feijão-guandu, mangalo

Centrosema brasiliana (L.) Benth.

Abre-caminho

Clitoria ternatea $\mathrm{L}$.

Abre-caminho, piriquitiinho

Crotalaria retusa $\mathrm{L}$

Guizo-de-cascavel

Dioclea grandiflora Mart. ex Benth.

Mucunã, parreira-brava

Dioclea virgata (Rich.) Amshoff

Cipó-pixuma, feijão-de-boi

Diplotropis ferruginea Benth.

Sucupira-preta

Erythrina velutina Willd.

Mulungu

Indigofera suffruticosa Mill.

Anil

Machaerium opacum Vogel

Jacarandá-muchiba

Periandra mediterranea (Vell.) Taub.

Alcaçuz, alcaçuz-da-terra

Pterocarpus violaceus Vogel

Pau-sangue

Pterodon emarginatus Vogel

Sucupira-branca, fava-de-santo-inácio

Rhynchosia minima (L.) DC.

Feijãozinho

Swartzia flaemingii Raddi

Jacarandá

Zornia brasiliensis Vogel

Urinária, urinana carrapicho

Zornia diphylla (L.) Pers.

Urinana, quebra-panela, quebra-tijela

Zornia glabra Desv.

Urinária, urinãna

\section{FABACEAE-MIMOSOIDEAE}

Anadenanthera colubrina var. cebil (Griseb.)Altschul Angico, angico-vermelho, angico-de-casca

Calliandra depauperata Benth.

Carqueija
Stem-bark

Fruits

Stem-bark

Leaves

Entire plant

Roots

Seeds

Entire plant

Roots

Leaves

Seeds

Stem-bark

Stem-bark

Fruit dried

Leaves

Roots

Folhas

Roots

Stem-bark

Stem-bark

Seeds

Entire plant

Leaves

Stem-bark

Entire plant

Entire plant

Entire plant

Leaves, stem-bark and roots affected until complete scar disappears.

As adjuvant in treatment of sinusitis. The same recipe as above. It is used for nasal inhalation. In treatment of urinary infections. A maceration of a handful in a liter of water. It is drunk substituting the water until the symptoms disappear.

A decoction against vaginal ulcers. It is used in baths and washes.

A decoction is drunk against rheumatism.

As vermifuge. A decoction of a handful in a liter of water. It is drunk as tea until the symptoms disappear.

An infusion as purgative and vermifuge.

Against vomits and amenorrhea

As poisonous.

Against prostate inflammations. A handful in decoction in a liter of water. It is drunk substituting the water until the symptoms disappear.

The decoctions against fevers and malaria.

As poisonous.

A decoction is drunk against inflammations and vaginal ulcers. It is also used in baths and washes external ulcers.

In the treatment of insomnia, coughs and as vermifuge. An infusion or decoction of a handful in a liter of water. It is drunk before sleep.

Against tooth aches. It is used as cigarette.

An infusion of a spoonful in a cup of water. It is drunk as stomachic after the meals.

A handful in decoction in a liter of water as diuretic. It is drunk as tea until the symptoms disappear.

An infusion is drunk as vermifuge before the breakfast.

A decoction of a handful in a liter of water is used against e diabetes. As syrup is used against bronchitis and tosses.

The decoction is used against tosses and external ulcers.

A decoction as anti-rheumatic.

A decoction as anti-inflammatory and depurative. The external use against acnes and skin freckles. As poisonous.

A decoction against liver diseases.

A decoction as anti-rheumatic.

As diuretic and against venereal diseases A handful in decoction in a liter of water. It is drunk as water until the symptoms disappear.

The same indications and uses as above.

The same indications and uses as above.

Against coughs, whooping coughs and bronchitis. A maceration of a handful in a liter of wine or "cachaça". It is drunk until the is drunk three times a day until the symptoms disappear.

As narcotic and poison. In maceration or infusion of a handful in a liter of water. It drunk before sleep.

A decoction against diabetes. It is drunk substituting the water. As gargling is used against infections of throat. 
Chloroleucon dumosum (Benth.) G.P.Lewis Jurema-branca

Chloroleucon foliolosum (Benth.) G.P.Lewis

Jurema-branca, treadina

Enterolobium contortisiliquum (Vell.)Morong

Timbaúba, orelha-de-negro, tambor

Inga alba (Sw.) Willd

Ingá-xixi

*Leucaena leucocephala (Lam.) de Wit

Linhaça

Mimosa acutistipula (Mart.) Benth.

Jurema-preta

Mimosa arenosa (Willd.) Poir.

Calumbi

Mimosa caesalpiniifolia Benth.

Sabiá

Mimosa candollei R.Grether

Malicinha-da-roça

Mimosa ophthalmocentra Mart. ex Benth.

Jurema-preta

Mimosa tenuiflora (Willd.) Poir

Jurema, jurema-preta

Mimosa verrucosa Benth.

Jurema

Piptadenia obliqua (Pers.) J.F.Macbr.

Angico-de-bezerro

Piptadenia viridiflora (Kunth) Benth.

Jacurutu, espinheiro-preto

Pithecellobium cochliacarpum (Gomes) J.F.Macbr.

Barbatimão

*Prosopis juliflora (Sw.) DC.

Albarobo, Algaroba, Algarobeira, Algarobia

FLACOURTIACEAE

Casearia sylvestris Sw.

Lígua-de-tio

HELICONIACEAE

Heliconia psittacorum L. f.

Bananeirinha do mato, pacova-catinga

\section{KRAMERIACEAE}

Krameria tomentosa A St.-Hil.

Carrapicho

\section{LAMIACEAE}

*Aeollanthus suaveolens Mart. ex Spreng.

Macassar, macassá

Hypenia salzmannii (Benth.) Harley Leaves

Canela-de-urubu

Hyptis macrostachys Benth.

Leaves

Stem-bark

Stem-bark

Stem-bark

Fruits

Stem-bark

Oil of seeds

Stem-bark

Leaves

Stem-bark

Roots

Stem-bark

Stem-bark

Leaves

Stem-bark

Stem-bark

Stem-bark

Stem-bark

Leaves

Leaves

Leaves

Roots

Leaves

Alfavaca-brava, hortelã-do-mato
A decoction of a small piece in a cup of water. It is drunk against fevers and anemia, until the symptoms disappear.

A decoction of a small piece in a cup of water. It is drunk against fevers, hemorrhages and anemia, until the symptoms disappear.

As anti-inflammatory. A decoction of a small piece in a cup of water. It is drunk until the symptoms disappear.

Against scabies. It is used as soap to wash the area infested.

A decoction of a handful in a liter of water. It is drunk as emetic.

As poultice against external inflammations.

As sedative and against diarrhea. A decoction of a small piece in a cup of water. It is drunk until the symptoms disappear.

A decoction as anti-rheumatic and as poultice against bruises.

As expectorant and against respiratory diseases. As syrup of a small piece in a cup of water and sugar. It is drunk until the symptoms disappear.

As diuretic. A decoction of a small piece in a cup of water. It is drunk until the symptoms disappear. Against bronchitis and coughs. A decoction of a handful in a liter of water or as syrup. It is drunk until the symptoms disappear.

Against bronchitis and coughs. The same use as above.

Against external ulcers. A decoction for baths and washes.

As sedative and narcotic. A decoction of a handful in a liter of water or as syrup. It is drunk until the symptoms disappear.

As haemostatic and digestive. A decoction of a handful in a liter of water. It is drunk until the symptoms disappear. The external use against furunculous.

The decoction against asthmas, intestinal spasms and toothaches.

The decoction is used against inflammations of uterus and for wash external ulcers and acnes.

An infusion, decoction and syrup. It is used against asthma and bronchitis. Dropped into the eyes against conjunctivitis.

A decoction against snake bite.

The topical use as emollient, against external ulcers and skin burned.

A decoction against diarrhea and the topical use against vaginal ulcers.

The juice is dropped into the ears against ear pains.

Against grippes, colds and respiratory diseases An infusion or decoction of a handful of leaves in two cups of water. It is drunk as tea until the symptoms disappear.

Against asthmas, coughs and bronchitis. An infusion of a spoonful in a cup of water. It is drunk as tea or as syrup 3 times daily until the symptoms disappear. 
Hyptis pectinata (L.) Poit.

Alfazema-brava, Betônica brava, canudinho

Hyptis suaveolens (L.) Poit.

Alfazema-de-caboclo, alfavaca-brava

Hyptis umbrosa Salzm. ex Benth.

Bamburral

**Lavandula $\mathrm{sp}$

Alfazema-verdadeira

Leonotis nepetifolia (L.) R.Br.

Cordão-de-são-francisco

Leucas martinicensis (Jacq.) R. Br.

Cordão-de-frade, cordão-de-são-francisco

Marsypianthes chamaedrys (Vahl)Kuntze

Hortelã-do-mato, bentônica-brava

*Mentha $x$ villosa-nervata Opiz

Hortelã-da-folha-miúda

Ocimum americanum $\mathrm{L}$.

Remédio-de-vaqueiro

*Ocimum basilicum $\mathrm{L}$.

Manjericão, manjericão-menino

Ocimum campechianum Mill.

Alfavaca, alfavaca-de-galinha

*Ocimum gratissimum L.

Louro, alfavaca, alfavaca-de-cheiro, quioiô-branco, tioiô, quioiô

*Plectranthus unguentarius Codd

Hortelã-graúda

*Rosmarinus officinalis L.

Alecrim, alecrim-verdadeiro

\section{LAURACEAE}

*Cinnamomum zeylanicum Blume

Canela

*Persea americana Mill.

Abacate

LECYTHIDACEAE

Eschweilera ovata (Cambess.) Miers

Biriba, biriba-branca, biriba-preta, ibiraba, imbiriba,

sapucaínha,

Lecythis pisonis Cambess

Sapucaia, cumbuca-de-macaco
Flowers

Flowers

Flowers

Flowers

Seeds

Leaves

Flowers

Flowers

Leaves

Entire plant

Leaves and flowers

Leaves and aerial parts

Entire plant

Leaves

Leaves

Leaves

Leaves

Leaves

Leaves

Leaves

Leaves or entire plant

Stem-bark or

leaves

Leaves

Seeds

Oil's seeds
Against dysmenorrheal and liver disorders. An infusion of a spoonful in a cup of water. It is drunk as tea four to six times a day until the symptoms disappear. Against asthmas, coughs and bronchitis. The same recipe and use as above or as syrup Against dysmenorrheal, respiratory diseases and as febrifuge. An infusion or decoction of a spoonful in a cup of water. It is drunk as tea. As digestive.

The same recipe as above. It is used in warm baths. As a cigarette during the symptoms. Against tooth ache and headache.

To withdraw small pieces of dust from the eyes. Put a small seed into the eye.

The juice is used in the treatment of nasal and auriculars diseases. A decoction as stomachic and tonic. A syrup as expectorant.

The infusion is used against headaches and as sedative for babies.

A decoction against diarrheas.

As anti-inflammatory of external ulcers and antiallergic.

As expectorant, anti-asthmatic, anti-rheumatic, febrifuge, diuretic and stomachic.

A decoction of a handful in a liter of water as sedative. It is drunk as tea until the symptoms disappear.

Against kidney disorders and inflammations. A decoction of a handful in a liter of water. It is drunk as tea until the symptoms disappear. Against rheumatism. The same recipe as above. It is used as washes for the affected areas.

As a carminative and digestive. An infusion of a handful in a cup of water. It is drunk as tea after the meals. As febrifuge and against bronchitis and coughs.

The same recipe as above or as syrup with honey. A teaspoon is used four times for day.

As syrup or juice against amoebas and verminoses. An infusion against bronchitis and as expectorant.

An infusion or as syrup against asthmas, fevers, tosses, grippes, bronchitis and as stomachic and digestive.

The same uses and indications as $O$. americanum.

The same uses and indications as above.

As emenagogue, stomachic, digestive, purgative and expectorant. It is used as decoction or syrup.

An infusion or as syrup as emenagogue, stomachic, digestive, purgative and expectorant.

As stomachic, digestive and anti-hypertensive. A handful in a cup of water. It is drunk as tea after the meals.

As stomachic, digestive and hypertensive. A decoction of a teaspoon in a cup of water. It is drunk as tea after the meals .

An infusion of a handful in a liter of water is used against renal diseases and as diuretic.

As tonic and source of protein. It is eaten as food.

An oil extracted from seeds is used as emollient against muscle pains.

The same use and indications as above. 
Loasa rupestris Gardner

Urtiga-branca

\section{LOGANIACEAE}

Spigelia anthelmia $\mathrm{L}$.

Arapabaca, lombrigueira, pimenta- d'água

Strychnos atlantica Krukoff \& Barneby

Capitãozinho

Strychnos parvifolia A.DC.

Capitãozinho, capitãozinho-preto, capitão, carrasco-preto

Strychnos trinervis (Vell.) Mart.

Capitão-preto, esporão-de-galo, cipó-cruzeiro, quina-

cruzeiro, quina

\section{LORANTHACEAE}

Phthirusa pyrifolia (Kunth) Eichler

Erva-de-passarinho

\section{MALPIGHIACEAE}

Byrsonima crassifolia (L.) Kunth

Murici-da-praia, murici-do-cerrado

Byrsonima sericea DC.

Murici-da-mata

Byrsonima verbascifolia (L.) DC.

Murici-de-tabuleiro, douradinha falsa

Mascagnia rigida (A.Juss.) Griseb.

Mata-rato, tingui

MALVACEAE

* Abelmoschus esculentus (L.) Moench

Quiabo

*Gossypium barbadense L.

Algodoeiro, algodão

Pavonia cancellata $(\mathrm{L}$.$) Cav.$

Malva, malva-de-rama

Sida cordifolia $\mathrm{L}$.

Malva-veludo, malva-branca, malva, malvão

Sida spinosa $\mathrm{L}$

Malva-lanceta, malva-relógio

Entire plant

Leaves

Sidastrum micranthum (A.St.-Hil.) Fryxell

Ervanço, malva-preta, guaxima

Entire plant

Leaves

MARANTACEAE

Ischnosiphon rotundifolius (Poepp. \& Endl.) Körn.

Surucucu

\section{MELIACEAE}

Carapa guianensis Aubl.

Andiroba

Cedrela odorata $\mathrm{L}$.

Cedro

Roots

Entire plant

Roots

bark, Roots

roots

Leaves

Stem-bark

Stem-bark

Entire plant

Seeds

Seeds

Leaves

Leaves

Leaves
Stem-bark

Seeds

Stem-bark

Leaves, stem-bark

Leaves and stem-

Leaves, stem-bark, The same indications and uses as above.

An infusion against tosses. The juice against verminoses.

An infusion is used against coughs gastrointestinal disorders as diarrheas, dermatitis and also against snake bite.

A decoction against fevers and diarrheas, syphilis and kidney diseases.

The same uses and indications as above.

As poison. The plant mixed with food is used to kill rats.

Roasted and grounded "as café". It is used as antirheumatic and laxative.

The decoction is used against venereal diseases and inflammations of urinary throat. The grounded seeds are used externally against burned skin. It is used as poultice against furunculous.

Against acnes. An infusion of a spoonful in a cup of water. It is used as wash in the affected skin. In the treat of coughs and leucorrhea. The same recipe as above. It is drunk as tea. As syrup, a spoonful is drunk four times a day until the symptoms disappear.

As anti-asthmatic, against grippes and respiratory diseases. An infusion of a spoonful in a cup of water. It is used as wash in the affected skin.

As emollient and against external ulcers and insect bites. The leaves in hot butter or olive oil as poultice in affected area.

Against bronchitis, coughs and asthmas. An infusion of a spoonful in a cup of water. It is drunk as tea.

As emollient. It is used as poultice with hot butter or olive oil.

Used against snake bite.

A decoction against fevers, rheumatism, and external ulcers.

A decoction of grounded seeds. It is used in baths against pediculosis.

A decoction against venereal diseases. 
Guarea guidonia (L.) Sleumer

Jitó, macaqueiro

MENISPERMACEAE

Chondrodendron platiphyllum A.St.-Hil. (Miers)

Cissampelos glaberrima A.St.-Hil.

Parreira, abuta

Cissampelos sympodialis Eichler

Milona

MONIMIACEAE

**Peumus boldus Molina

Boldo, boldo-do-chile

MORACEAE

Brosimum gaudichaudii Trécul

Mama-de-cadela

Dorstenia brasiliensis Lam.

Contra-erva, carapiá

MORINGACEAE

* Moringa oleifera Lam.

Moringa

MUSACEAE

*Musa paradisiaca L.

Bananeira, banana

\section{MYRTACEAE}

Eugenia dysenterica DC.

Cagaita

Eugenia uniflora L.

Pitanga

Myrciaria cauliflora (Mart.) O. Berg

Jabuticaba

Psidium guajava L.

Goiaba

Psidium guineense Sw.

Araçá, araçá do campo

\section{NYCTAGINACEAE}

Boerhavia coccinea Mill.

Pega-pinto, batata-de-porco

Guapira pernambucensis (Casar.) Lundell.

João-mole

Guapira laxiflora (Choisy) Lundell

João-mole

*Mirabilis jalapa L.

Bonina

\section{NYMPHAEACEAE}

Nymphaea pulchella DC.

Aguapé-branco

Nymphaea rudgeana G. Mey.

Aguapé-branco

\section{OCHNACEAE}

Ouratea hexasperma (A.St.-Hil.) Baill.

Batiputá

Ouratea parvifolia (A.St.-Hil.) Engler

Batiputá
Stem-bark

A decoction against verminoses and as abortive.

Entire plant As poisonous.

Roots

Roots

Leaves

Stem-bark and

leaves

Roots

Fruits and leaves

Leaves

Fruit

Leaves

Leaves

Leaves and stem-

bark

Leaves

Leaves

Roots

Stem-bark

Roots

Flowers

Seeds

Entire plant

Fruits

Fruits
An infusion or decoction against tosses, bronchitis and respiratory diseases.

An infusion or decoction against tosses, bronchitis and respiratory diseases.

An infusion of a handful in a liter of water. It is used as tea or cold against liver diseases and as digestive and stomachic.

The decoction is used against vitiligo and skin diseases.

A decoction or as syrup against tosses and bronchitis.

The decoction against skin diseases. It is used in bath or for wash the affected area. Against diseases of respiratory system and articulations.

A decoction against external ulcers and burned skin.

As food in nature against vascular diseases. The fruit grilled with the epicarp is used against diarrheas and dysenteries.

The decoction or infusion is drunk against diarrheas and dysenteries.

The same uses and indications as above.

A decoction is drunk against diarrheas and dysenteries. The syrup is used against tosses and bronchitis.

The same use and indication as Eugenia

dysenterica.

The same use and indication as Eugenia

dysenterica.

As diuretic and against liver diseases. A decoction of a handful in a liter of water. It is drunk as tea until the symptoms disappear.

As caustic and irritant of skin.

The decoction is drunk against rheumatism and sexual diseases and as aphrodisiac.

The infusion against leucorrhea. It is used 2-3 times daily. Dropped into the ears against inflammations and pains.

The grounded seeds are applied externally against ulcers and acnes.

A decoction against diarrheas and inflammations of prostate, treat urinary and ovaries.

The same uses and indications as above.

The oil extracted from the fruits by the heat against ear pains. It is dropped into the ears until the pain disappears.

The same uses and indications as above. 
OLACACEAE
Ptychopetalum olacoides Benth.

Muirapuama

Ximenia americana L.

Ameixa

Roots

Stem-bark

PAPAVERACEAE

Argemone mexicana L.

Cardo-santo

PASSIFLORACEAE

Passiflora cincinnata Mast.

Maracujá-mochila, maracujá-do-mato

*Passiflora edulis Sims

Maracujá

Passiflora foetida L.

Camapu, maracujá-de-estalo, maracujá-catinga

PEDALIACEAE

Gergelim

\section{PHYLLANTHACEAE}

Phyllanthus claussenii Müll.Arg.

Quebra-pedra

Phyllanthus niruri L.

Quebra-pedra

PHYTOLACCACEAE

Petiveria alliacea $\mathrm{L}$

Tipí, guiné

PIPERACEAE

Ottonia leptostachya Kunth

Jaborandi

Peperomia pellucida (L.) Kunth

Língua-de-sapo, alfavaca-de-cobra, alfavaquinha-de-cobra

Piper aduncum L.

Pimenta-darda, pimenta-e-macaco

Piper arboreum Aubl.

Fruto de morcego, alecrim-de-angola, pau-de-angola, betopreto

Piper marginatum Jacq.

Malvaisco

Pothomorphe umbellata (L.) Miq.

Caápeba

PLUMBAGINACEAE

Plumbago scandens L.

Louco

POACEAE

*Coix lacryma-jobi L.

Capim de contas, conta-de-nossa-senhora
*Sesamum indicum L.
The decoction is drunk againts rheumatism and as aphrodisiac.

The maceration is used as diuretic and against ovarian and prostatic inflammations.
Seeds

Latex

As purgative, laxative and digestive. An infusion or decoction of a teaspoon in a cup of water. It is drunk as tea after meals.

Against conjunctivitis. The latex is dropped into the eyes.

Leaves

Fruit

Leaves

Mesocarp

Entire plant

Leaves

Leaves

Seeds

Leaves

Leaves

Leaves

Roots

Entire plant

Entire plant

Inflorescence

Inflorescence

Inflorescence

Inflorescence

Leaves

Entire plant

Leaves

Seeds

Against venereal diseases and hemorrhoids. A decoction of a handful in a liter of water. It is drunk as tea.

The juice as sedative.

Against renal stones and as digestive, and diuretic.

It is dried and powdered and used as food against diabetes.

Against venereal diseases. A decoction of a handful in a liter of water. It is drunk as tea.

Against hemorrhoids. The same recipe as above. It is used for local baths.

An infusion against tosses and inflammations of the throat.

Roasted and grounded is used as hypotensive and source of vitamin.

The infusion and decoction against kidney diseases and sexual illness.

The same uses and indications as above.

The juice is used against toot pains.

A decoction of a handful in a liter of water as abortive. It is drunk until the menstruation appear.

Againts arthritis and as analgesic and sedative. Against warts. An infusion or decoction of a handful in a liter of water. It is drunk during the pain.

A decoction as diuretic. It is used also against general infections.

A decoction is used against venereal diseases and infections of the urinary throat.

The same indication and uses as above

The same indication and uses as $P$. aduncum. Against tooth aches

A decoction against liver and kidney diseases, migraine and headaches.

Smashed as poultice against external ulcers.

As an analgesic in arthritis and as sedative. An infusion or decoction of a handful in a liter of water. It is drunk during the pain.

The ground leaves are placed on warts as poultice.

A decoction as diuretic and against infections.

POLYGALACEAE 
Polygala gracilis Kunth

Roots

Arrozinho

Polygala martiana A.W.Benn.

Poaia, ipecacuanha

Polygala paniculata L.

Barba-de-são-pedro, alcaçuz, arrozinho

Roots

Roots

Polygala violacea Aubl.

Roots

Erva-iodeque

Polygala spectabilis DC.

Caninana

\section{POLYGONACEAE}

Polygonum punctatum Elliott

Pimenta-d'agua

\section{PORTULACACEAE}

Portulaca oleracea L.

Bredo, beldroega

Talinum triangulare (Jacq.) Willd.

Bredo, língua-de-vaca

PUNICACEAE

* Punica granatum L.

Romã, romanzeira

RHAMNACEAE

Zizyphus cotinifolia Reiss.

Juazeiro

Zizyphus joazeiro Mart.

Juazeiro, Joá, joazeiro, juá, juá-de-espinho

\section{RUBIACEAE}

Borreria verticillata (L.) G.Mey. var. verticillata

Vassourinha-de-botão

Chiococca alba (L.) Hitchc.

Cipó-cruz, caninana, cainco

Coutarea hexandra (Jacq.) K.Schum.

Quina-quina

Genipa americana L.

Jenipapo

Guettarda angelica Müll.Arg.

Angélica-brava, angélica-do-mato

Guettarda platypoda DC.

Angélica-do-mato

Richardia brasiliensis Gomes

Ervanço, poaia, ipeca

Richardia grandiflora (Cham. \& Schltdl.)Steud.

Ervanço, poaia, ipeca-mirim

Psychotria bracteocardia (DC.) Müll.Arg.

Mata-rato

Salzmannia nitida DC.

Cainca-vermelha
Roots

Roots

Stem-bark

Leaves

Leaves

Fruit epicarp

Leaves

Stem-bark

Roots

Roots

Stem-bark

Fruit

Leaves

Roots

Roots

Roots

Roots

Entire plant

Stem-bark
As diuretic, emetic and expectorant. An infusion or decoction of a handful in a liter of water. It is drunk substituting the water until the symptoms disappear.

Against blenorrheas

The same uses and indications as above.

As a diuretic, emetic and expectorant and against blenorrheas. An infusion or decoction of a handful in a liter of water. It is drunk substituting the water until the symptoms disappear. Against snake bites. The roots are eaten and placed above the affected area.

The same uses and indications as above.

Against snake bite. The roots are eaten and placed above the affected area.

A decoction against bronchitis and tosses. As syrup is used as expectorant, digestive and stomachic. The external use in baths or washes against seborrhea, dandruffs and dermatitis.

Against hemorrhoids and as vermifuge A handful as decoction in a liter of water. It is used before breakfast once only.

As laxative. It is cooked or eating as salad.

The decoction. It is used as gargling against infections and inflammations of the tract respiratory.

A decoction of a handful in a liter against diarrheas.

As toothpaste in treatment of teeth and gum. It is powdered and used directly to brush the teeth. Against dandruff. The same recipe as above. It is used as washes of the hairs.

The same uses and recipe as above.

As vermifuge and against hemorrhoids. A decoction of a handful in a half of liter of water. It is used once before the breakfast.

A decoction of a handful in a liter of water. It is used against rheumatism and indigestions. It is used also against snake bite.

A decoction of a handful in a liter is used as febrifuge. It is used against malaria, bronchitis and hepatitis. The external use in bath is applied against dandruffs.

It is used as tonic against anemia

The infusion is drunk against liver diseases.

Against menstrual spasms, constipation and fevers An infusion or decoction of a small piece in a cup of water. It is drunk as tea during the pains.

The same indication and uses as above.

Against hemorrhoids and as vermifuge A handful as decoction in a liter of water. It is used before breakfast once only.

The same indication and uses as above.

It is used with food to kill mouses.

A decoction as febrifuge and used against toot pains. 
Tocoyena formosa (Cham. \& Schltdl.)K.Shum.

Jenipapim, jenipapo-bravo

Leaves

\section{RUTACEAE}

*Citrus maxima (Burm. ex Rumph.) Merr.

Laranjeira

*Citrus medica $\mathrm{L}$.

Limoeiro

Ertela trifolia (L.) Kuntze

Alfavaca-de-cobra

Fagara rhoifolia (Lam.) Engl.

Limãozinho

Pilocarpus jaborandi Holmes

Jaborandi, joão-barondi

Pilocarpus microphyllus Stapf

Jaborandi

*Ruta graveolens $\mathrm{L}$

Arruda

SAPINDACEAE

Allophylus edulis (A.St.-Hil., Cambess. \& A.Juss.) Radlk. Fruta-de-paraó

Cardiospermum corindum $\mathrm{L}$.

Para-tudo, balãozinho, camapú, saco-de-padre

Paullinia pinnata $\mathrm{L}$.

Mata-fome, cururu-apé

Sapindus saponaria L.

Sabonete, jitó

Serjania glabrata Kunth

Timbó

Talisia esculenta (A.St.-Hil.) Radlk.

Pitombeira

\section{SAPOTACEAE}

Sideroxylon obtusifolium (Roem. \& Schult.) T.D. Penn.

Quixaba, rompe-gibão

\section{SCROPHULARIACEAE}

Capraria biflora $\mathrm{L}$

Chá-da-calçada

Scoparia dulcis L.

Vassourinha

Stemodia foliosa Benth.

Meladinha

Stemodia maritima L.

Meladinha

SELAGINELLACEAE

Selaginella convoluta (Arn.) Spring

Mão-fechada, jericó, mão-de-papagaio.

SOLANACEAE

Brunfelsia uniflora (Pohl) D.Don

Manacá

*Capsicum baccatum $\mathrm{L}$

Pimenta-de-cheiro

Against rheumatisms. The leaves are used as poultice in the affected area with hot olive oil or butter.

Leaves and fruit

skin

Flowers

Fruit

Leaves or aerial

parts, roots

Stem-bark

Stem-roots

Stem-bark and/or

leaves

Entire plant

Entire plant

Aerial parts

Bark

Leaves

Entire plant

Seeds

Leaves

Entire plant

Entire plant

Leaves and stembark

Entire plant

Roots

Entire plant

Roots

Aerial parts

Aerial parts

Entire plant

Roots and stem-

bark

Leaves

Fruits
The infusion of a handful in a liter of water or maceration in wine. It is used as sedative, stomachic and digestive.

An infusion of a spoonful as sedative

The juice is used against grippes and coughs.

A decoction or infusion against fevers and malaria Against snake bite.

A decoction or infusion against fevers and as stomachic.

A decoction against rheumatism.

A decoction as febrifuge and sudorific. It is used against tooth pains.

As poisonous.

The same uses and indications as above.

An infusion of a handful in a liter of water or maceration in wine. It is as used as abortive and against amenorrhea.

The decoction against external ulcers An infusion against kidney diseases.

Against liver disorders and rheumatisms. As tonic for memory, diuretic and emenagogue. An infusion or decoction of a handful in a liter of water. It is drunk as tea until the symptoms disappear.

An infusion against hydropsies.

An infusion as ophthalmic. It is also used against uterine inflammations and kidney diseases. The external uses as emollient.

As poisonous and used as insect repellent.

It is mixed with food to kill rats.

The decoction or as syrup against tosses and as expectorant.

Against ovarian inflammations and diabetes. A decoction or maceration of a handful in a liter of water. It is drunk "as water" or tea until the symptoms disappear.

The decoction as purgative, emetic, abortive and used against rheumatism.

Against amenorrhea and as vermifuge. A decoction of a handful in a liter of water. It is drunk as tea. As anti-diabetic. The same recipe and use as above As insect repellent. The fresh plant is scrubbed on the skin.

The same use and indication as above.

As aphrodisiac and diuretic and against amenorrhea. A decoction of entire plant in two cups of water. It is used as tea three times daily.

The infusion or decoction as depurative emetic, abortive and purgative. It is used against rheumatism and as sedative.

Used as cataplasm with butter or olive oil against furunculous.

As food mixed with the meals against anorexia. 
*Capsicum frutescens $\mathrm{L}$.

Pimenta-malagueta

Capsicum parvifolium Sendtn.

Pimentinha-brava

*Datura metel L.

Zabumba-roxa

Datura stramonium L.

Zabumba-branca, estramônio, zabumba, figueira,

trombeteira, mata-zombando

Nicandra physalodes (L.) Gaertn.

Quintilho

Nicotiana glauca Graham

Fumo-bravo, charuto-do-rei

Physalis angulata L.

Camapu, bate-testa, juá

Physalis pubescens L.

Camapú, balãozinho

Solanum agrarium Sendtn.

Gogóia, baba

Solanum americanum Mill.

Aguiraquia, erva-moura

Solanum asperum Rich.

Jussara, coca-coça

Solanum asterophorum Mart.

Jurubeba-de-fogo

Solanum caavurana Vell.

Jurubeba-branca

Solanum capsicoides All.

Arrebenta-boi

Solanum crinitum Lam.

Jurubeba-grande, jurubebão

*Solanum lycopersicum L.

Tomate

*Solanum melongena L.

Beringela

Solanum palinacanthum Dunal

Jurubeba

Solanum paludosum Moric.

Jurubeba-brava, jurubeba-roxa

Solanum paniculatum L.

Jurubeba, jurubeba-roxa

Solanum rhytidoandrum Sendtn

Jurubeba-branca

Solanum stipulaceum Roem. \& Schult.

Jussara-roxa, jurubeba-roxa

Solanum stramonifolium Jacq.

Jurubeba-branca-doce

Solanum torvum $\mathrm{Sw}$.

Jurubeba, jurubeba-branca

STERCULIACEAE

Guazuma ulmifolia Lam.

Mutamba
Leaves and fruits

Leaves

Flowers

Seeds

Flowers

Entire plant

Leaves

Leaves

Entire plant

The same use and indication as above.

The same use and indication as Capsicum baccatum.

As anti-asthmatic and sedative as cigarettes.

A teaspoon of seeds in infusion in a cup of water. It is drunk as tea.

Against asthmas and imsonias. The same recipe and use as above.

As fly poison. A decoction of a handful in a liter of water. It is used as wash for the floor.

Against asthmas and migraine It is used as cigarette during the crisis of asthma or migraine. As poisonous

As sedative and against inflammations of bladder and spleen and kidney. An infusion of a handful in a liter of water. It is drunk as tea until symptoms disappear. As sedative it is drunk at night.

Against dermatitis and optitis. A handful as decoction in $1 / 2$ liter of water. It is used as wash for the skin or dropped into the auricular channel.

Fruit and entire The same uses and indications as above.

plant

Roots

As abortive and against prostates inflammations. A decoction of a handful in two parts of water. It is drunk substituting water until the symptoms disappear.

Leaves

External ulcers. The dried leaves are powdered. It is used in local application until the ulcer disappear. Against insomnias. A decoction or infusion of a part for two of water. It is used as tea at night.

Leaves

Roots

Roots

Fruit

Fruit

Fruit

It is irritant and allergic to the skin.

Against liver diseases A decoction of a handful in a liter of water. It is drunk as tea after meals.

Against liver diseases A decoction of a handful in a liter of water.

It is drunk as tea after meals substituting $S$. paniculatum.

As poisonous.

As poisonous and used to kill cucarachas.

Fruit

Fruit

Fruit

Roots

Fruit

Roots

Fruits

Roots

Fruits

Roots

Roots and fruits

Stem-bark

Leaves
The juice as diuretic and refreshing

The external use in skin as emollient. It is used as juice against high level of cholesterol.

As poisonous.

The infusion is used against hepatic diseases.

As poisonous.

As diuretic and against diseases of liver. The same recipe and use as above.

As anti-anemic and against tuberculosis. The fresh juice used three times a day until the symptoms disappear.

Against liver diseases A decoction of a handful in a liter of water. It is drunk as tea after meals.

As poisonous.

The same indications and uses as $S$. paniculatum.

The same indications and uses as substitute of $S$. paniculatum.

The decoction of a handful in a liter of water as hair tonic. It is used in baths against dandruffs and external ulcers. 
Melochia pyramidata L.

Malva-roxa

Leaves

Melochia tomentosa L.

Malva-preta

Sterculia striata A.St.-Hil. \& Naudin

Chichá

Waltheria indica $\mathrm{L}$.

Malva, malva-branca

Waltheria viscosissima A.St.- Hil.

Malva-preta

Leaves

\section{TURNERACEAE}

Piriqueta racemosa (Jacq.) Sweet

Malva-de-vassoura

Turnera subulata L.

Chanana

Leaves

Roots

Leaves

Leaves

Entire plant

Roots

Roots

Entire Plant

URTICACEAE

Laportea aestuans (L.)Chew

Ortiga-vermelha

\section{VERBENACEAE}

Lantana camara L.

Chumbinho, camará, cambará

Lantana radula Sw.

Chumbinho-branco

Lippia alnifolia Schauer

Alecrim-do-mato

Lippia gracilis Schauer

Alecrim-pimenta, alecrim-de-serrote, alecrim-da-chapada

Lippia microphylla Cham.

Alecrim-do-mato, alecrim-de-tabuleiro, alecrim-pimenta

Stachytarpheta cayennensis (Rich.) Vahl

Gervão

Stachytarpheta elatior Schrad. ex Schult.

Gervão

* Vitex agnus-castus L.

Liamba, teca

Vitex gardneriana Schauer

Jaramataia, tamanqueira

VIOLACEAE

Hybanthus calceolaria (L.) Schulze-Menz

Ipecacoanha, ipepacoanha, ipeca

\section{VISCACEAE}

Phoradendron strongyloclados Eichler

Erva-de-passarinho

\section{VITACEAE}

Cissus coccinea (Baker) Mart. ex Planch.

Cipó-fogo, uva-branca, parreira-brava
Leaves

Leaves

Leaves

Leaves

Leaves

Leaves

Entire plant

Leaves

Leaves

Leaves

Roots

Roots

Leaves
Against coughs and bronchitis. A decoction of a handful in half liter of water or as syrup. It is drunk as tea three times a day until the symptoms disappear.

A decoction is used to facilitate in the childbirth.

Against inflammations in the throat.

The topical use with hot butter or olive oil against furunculous.

Against syphilis, coughs and bronchitis and external ulcers and acnes. A decoction of a handful in half liter of water or as syrup. It is drunk as tea three times a day until the symptoms disappear. The topical use against furunculous.

A decoction of a handful in half liter of water or as syrup against tosses and grippes.

As emollient. It is used externally.

A decoction against amenorrhea and as abortive.

Against amenorrhea and dysmenorrheal. A decoction of a handful in a liter of water. It is drunk as tea.

As expectorant, against bronchitis and coughs. As syrup. A spoonful is drunk four times per day.

Against inflammations and as anti-rheumatic. A decoction of a handful in half liter of water. It is drunk as tea until the symptoms disappear.

As emenagogue, diuretic, expectorant and antirheumatic. A decoction of a handful in half liter of water. It is drunk as tea until the symptoms disappear.

The decoction is used against tosses, grippes and bronchitis.

The decoction or maceration in alcohol. It is used as antiseptic for topical uses against dermatitis and dandruffs and as antiseptic oral.

The same uses and indications as above.

As antiseptic and against respiratory diseases The same recipe and use as above.

Against respiratory diseases. A decoction of a handful in a liter of water. It is drunk as tea until the symptoms disappear.

Against vitiligo. The same recipe as above. It is drunk and used for baths.

The same recipes, uses and indications as above.

An infusion against asthmas and kidney diseases.

An infusion as sedative and stomachic and against rheumatism.

As emenagogue. A decoction of a spoonful of handful in a liter of water. It is drunk as tea once a time at night. Against diarrheas and amoebas. The powder is made as pills mixed with Manihot's starch. It is used until the symptoms disappear.

The decoction against tosses and grippes and as vermifuge.

The infusion or decoction against kidney diseases. The external uses against warts and external ulcers. 
Cissus erosa Rich.

Cipó-fogo, uva-branca, parreira-brava

Cissus simsiana Schult. \& Schult.f Insulina vegetal, anil trepador

Cissus verticillata (L.) Nicolson \& C.E. Jarvis Parreira-brava

\section{ZINGIBERACEAE}

*Curcuma longa L.

Gengibre-amarelo, acafrão

*Etlingera elatior (Jack) R.M. Sm.

Colônia

*Zingiber officinale Roscoe

\section{ZYGOPHYLLACEAE}

Kallstroemia maxima (L.) Hook. \& Arn. Puíba, rabo-decalango
Aerial parts

Roots

Leaves

Leaves or aerial parts

Rhizome

Leaves

Flowers

Rhizome

Entire plant
The juice in topical use against warts and external ulcers. The decoction as analgesic and against leishmaniosis.

The infusion is used as diuretic against kidney diseases.

The infusion or maceration of a handful in a litter of water. It is used 3 times daily against diabetes. Against respiratory diseases. A decoction of a handful in a liter of water. It is drunk as tea until the symptoms disappear.

The powder is used against intestinal and stomachic diseases.

An infusion is drunk against grippes, colds and fevers.

A maceration in alcohol is used against headches.

It is used for gargle against throat diseases. An infusion or decoction is used against bronchitis, colds, tosses and as expectorant.

Smashed with hot butter or olive oil is applied externally against furunculous 